\title{
Economic burden of patients with diffuse large B-cell and follicular lymphoma treated in the USA
}

\author{
Vicki A Morrison ${ }^{1}$, Jill A Bell2 ${ }^{2}$ Laurie Hamilton ${ }^{3}$, Augustina Ogbonnaya*,3, Huai-Che Shih ${ }^{3}$, \\ Kristin Hennenfent ${ }^{3}$, Michael Eaddy ${ }^{3}$, Yaping Shou ${ }^{2}$ \& Aaron Galaznik ${ }^{2}$ \\ ${ }^{1}$ Hematology/Oncology \& Infectious Disease, Hennepin County Medical Center, University of Minnesota, 701 Park Ave Ste 310, \\ Minneapolis, MN 55415, USA \\ ${ }^{2}$ Millennium Pharmaceuticals Inc., (a wholly owned subsidiary of Takeda Pharmaceutical Company Limited), 40 Landsdowne St, \\ Cambridge, MA 0213, USA \\ ${ }^{3}$ Xcenda LLC, 4114 Woodlands Parkway, Suite 500, Palm Harbor, FL 34685, USA \\ *Author for correspondence: Augustina.Ogbonnaya@Xcenda.com
}

\begin{abstract}
Aim: Evaluate healthcare costs and utilization of treated diffuse large B-cell lymphoma (DLBCL) and follicular lymphoma (FL) patients. Materials \& methods: Adults with newly diagnosed DLBCL and FL between 1 January 2008 and 31 October 2015 were identified in the Optum ${ }^{T M}$ claims database. Healthcare costs and utilization were assessed from diagnosis date until end of follow-up. Results: A total of 1267 DLBCLand $1595 \mathrm{FL}$-treated patients were identified. Mean per-patient, per-month cost during follow-up was US $\$ 11,890$ for DLBCL and US\$10,460 for FL. Healthcare costs and utilization decreased from year 1 to 2 following diagnosis, due to a decrease in chemotherapy services, inpatient admissions and other outpatient services. Conclusion: The economic burden of treated DLBCL and FL is considerable, especially in the first year following diagnosis.
\end{abstract}

First draft submitted: 3 April 2018; Accepted for publication: 14 May 2018; Published online: 18 June 2018

Keywords: cost $\bullet$ diffuse large B-cell lymphoma $\bullet$ economic burden $\bullet$ follicular lymphoma $\bullet$ healthcare utilization $\bullet$ real-world $\bullet$ retrospective $\bullet$ treatment

Non-Hodgkin's lymphomas (NHL) are a heterogeneous group of lymphoproliferative malignancies with a wide array of histologic subtypes. In 2017, an estimated 72,240 patients will be diagnosed with NHL in the USA, and NHL will cause an estimated 20,140 deaths [1]. Diffuse large B-cell lymphoma (DLBCL) is the most common subtype of NHL, composing 30\% of the annual NHL diagnoses [2]. The incidence of DLBCL increases with age, with a median age of 60-70 years at diagnosis [2,3]. Follicular lymphoma (FL) is the second most common subtype of NHL, accounting for approximately $15-20 \%$ of adult NHL [4,5]. The average age of individuals diagnosed with FL is about 60 years [4]. It has been estimated that approximately $10 \%$ of FL will undergo a histologic transformation at 5 years, and rate of histologic transformation after 5 years will diminish [6].

Chemoimmunotherapy plays a role in the treatment of both DLBCL and FL; the majority of recommended chemoimmunotherapy regimens are anthracycline-based, with the addition of rituximab [7]. For patients who are refractory to or relapse following first-line treatment for DLBCL, subsequent treatment largely depends upon their candidacy for autologous stem cell transplant (SCT). There is currently no standard of care for patients with relapsed/refractory DLBCL who are ineligible for autologous SCT [8]. The decision to initiate treatment for FL is based largely on histologic grade and the extent of the disease [9]. Grade 3 FL is generally treated like DLBCL, while patients with grades 1 and 2 disease might be monitored without treatment or treated with radiation therapy [7,9]. For patients with grade 1 and 2 disease with an indication for treatment (i.e., threatened end-organ function, cytopenias, bulky disease or steady or rapid progression), treatment options generally include chemoimmunotherapy regimens, with rituximab frequently employed as the immunotherapeutic agent [7].

Recent estimates suggest that the cost of cancer care will increase by $27 \%$ by 2020 due to the aging population alone [10]. Another factor that will contribute to increased costs of cancer care will be the adoption of more 
expensive targeted treatments as standard of care [10]. Healthcare costs associated with DLBCL and FL have not been extensively studied in the USA in recent years. The available studies were conducted on the broad NHL population, used older data, evaluated costs over a short time period or had a limited scope. A study using data from 1999 to 2000 estimated that the mean monthly costs in the first 2 years of treatment were US $\$ 5871$ for patients with aggressive NHL versus US $\$ 355$ for controls $(\mathrm{p}<0.0001)$ and US $\$ 3833$ for patients with indolent NHL versus US $\$ 289$ for controls ( $\mathrm{p}<0.0001$ ) [11]. A study by Beveridge et al. reported the overall mean per-patient, per-month (PPPM) costs (in 2007 US\$) over a 6-month follow-up period to be US $\$ 3527$ for FL patients whose disease progressed versus US $\$ 860$ for FL patients whose disease did not progress [12]. A retrospective study of claims for patients with NHL or chronic lymphocytic leukemia evaluated the cost of care for rituximab when administered in the hospital outpatient setting versus physician office or clinic [13]. While fewer rituximab infusions were given in the hospital outpatient setting, this setting was associated with higher total healthcare costs, higher daily costs and a higher rate of emergency department (ED) visits and/or inpatient admissions.

Overall, the data are limited on current healthcare utilization and costs associated with treating DLBCL and FL in routine clinical practice. The objective of this study was to evaluate the healthcare utilization and costs associated with DLBCL and FL patients who were treated in routine clinical care in the USA.

\section{Methods}

Study design

This retrospective, observational study was conducted using administrative claims data from Optum ${ }^{\top M}$. The Optum claims database include healthcare plan data from 1993 to present date on more than 111 million patients from geographically diverse regions across the USA. The data are derived from commercial health plans and Medicare Advantage programs. Included in the data are medical and pharmacy claims, laboratory results, mental health claims, as well as commercial and Medicare enrollment information. The database can also be linked to other data sources, such as clinical/electronic medical record data, socioeconomic status data, mortality data, inpatient hospital detail records and health risk assessment data. Data from 1 January 2007 through 31 December 2015 were used for the current study, and the enrollment period during which DBLCL and FL patients were identified was from 1 January 2008 to 31 October 2015. The index diagnosis date was defined as the date of the first record of DLBCL diagnosis for DLBCL patients or FL diagnosis for FL patients. The 12-month period before the index diagnosis date was the baseline period, which was used to determine whether patients were newly diagnosed and treatment-naive. In addition, baseline characteristics were assessed during this period. The follow-up period was $\geq 60$ days from the index diagnosis date; however, patients who died within this 60-day period were followed for less than 60 days. The follow-up period ended upon death, loss to follow-up or end of study (i.e., 31 December 2015). For patients with an FL diagnosis, progression to DLBCL also ended follow-up.

\section{Study population \& enrollment criteria}

Patients with newly diagnosed DLBCL, identified during the enrollment period by $\geq 1$ inpatient claim with a DLBCL diagnosis code or $\geq 2$ outpatient claims with a DLBCL diagnosis code (International Classification of Diseases, 9th Revision [ICD-9]: 200.7 and 200.7 $\times$ and International Classification of Diseases, 10th Revision [ICD-10]: C83.3×, C84.6×, C84.7×, C85.2 $\times$ and C93.3) that were $\geq 60$ days but within 1 year apart, were included. Newly diagnosed FL patients were also identified during the enrollment period by the presence of $\geq 1$ inpatient claim with an FL diagnosis code or $\geq 2$ outpatient claims with an FL diagnosis code (ICD-9 code: 202.xx; ICD-10 code: C82.xx) that was $\geq 60$ days but within 1 year apart. The resulting DLBCL and FL populations were subjected to the following additional inclusion criteria: aged 18 years or older at the index diagnosis date; having continuous enrollment, with medical and pharmacy benefits, for 12 months in the baseline period and $\geq 60$ days in the follow-up period; and receipt of DLBCL-related treatment for DLBCL patients and FL-related treatment for FL patients following the index diagnosis date. DLBCL patients were excluded if they had any evidence of DLBCL during the baseline period or FL or other NHL diagnosis $\geq 30$ days from the index diagnosis date. FL patients were excluded if they had any evidence of FL during the baseline period. Additional exclusion criteria for both DLBCL and FL patients were evidence of other primary cancers or metastatic disease in the baseline period, receipt of any chemoimmunotherapy or SCT in the baseline period, receipt of only SCT in the follow-up period or SCT without chemoimmunotherapy as the first line of therapy (LOT) or presence of inconsistent data (e.g., date of death reported prior to index diagnosis date). 


\section{Study measures}

Age, gender, geographic region, payer type and year of diagnosis were evaluated on the index diagnosis date, while Charlson comorbidity index (CCI) and the individual CCI comorbidities were evaluated during the baseline period. DLBCL- and FL-related treatments in the follow-up period were also evaluated. For DLBCL, first-line therapy was defined as all agents received within 60 days following the day of first infusion or fill date for a chemoimmunotherapy agent; a subsequent LOT was triggered by the addition or substitution of a new agent in the prior LOT after 60 days, or initiation of treatment after $\geq 180$ days following the run-out date of all agents in the prior LOT. For FL, first-line therapy was defined as all agents received within 90 days following the day of first infusion or fill date for a chemoimmunotherapy agent; a subsequent LOT was trigged by the addition or substitution of a new agent in the prior LOT after 90 days or initiation of treatment initiated after $\geq 180$ days following the run-out date of all agents in the prior LOT. Receipt of SCT and supportive care (e.g., erythrocyte/platelet transfusions; thrombopoietic-, erythropoietic- and granulocyte colony-stimulating factors; hydroxyurea; antifungals; and pain medications) during the LOTs was also evaluated. Time to treatment initiation was defined as the time from index diagnosis date to the first evidence of chemoimmunotherapy. Duration of therapy was defined as the time from treatment initiation of an LOT to the last day of therapy for that LOT.

\section{Study outcomes}

Healthcare utilization and costs that were incurred from the index diagnosis date through the end of follow-up were evaluated; yearly healthcare utilization and costs following the index diagnosis date were also evaluated. Costs, which were based on the actual paid amount, were adjusted to 2015 US\$ using the Bureau of Labor Statistics' medical care component of the Consumer Price Index. Patients with a capitated payment plan were excluded from the cost analysis.

Healthcare utilization and costs were evaluated separately for DLBCL and FL patients. For each cohort, all-cause, disease-related and nondisease-related healthcare utilization, and costs were reported. All-cause medical utilization and costs included all medical claims, regardless of the primary ICD-9 or ICD-10 diagnosis code on the claim, and all pharmacy claims. Medical utilization and costs were deemed DLBCL-related if the primary ICD-9 or ICD-10 diagnosis code on the claim was for DLBCL or the patient had DLBCL-related chemoimmunotherapy, radiation therapy or supportive care code on the claim, while DLBCL-related outpatient pharmacy utilization and costs included prescription claims for DLBCL-related chemoimmunotherapy or supportive care. Similarly, medical utilization and costs were deemed FL-related if the primary ICD-9 or ICD-10 diagnosis code on the claim was for FL or the patient had FL-related chemoimmunotherapy, radiation therapy or supportive care code on the claim, while FL-related outpatient pharmacy utilization and costs included prescription claims for FL-related chemoimmunotherapy or supportive care. In both cohorts, claims related to chemoimmunotherapy, radiation therapy and supportive care visits could occur in any setting of care. All medical and outpatient pharmacy claims not categorized as DLBCL-related were considered non-DLBCL-related, and all claims not categorized as FL-related were considered non-FL-related.

Healthcare utilization categories included medical services, composed of inpatient admissions (including length of stay), ED visits, outpatient physician office visits, other outpatient office visits, chemoimmunotherapy visits, radiation therapy visits and supportive care visits. Visits for chemoimmunotherapy, radiation therapy and supportive care were only counted within these categories and were excluded from visits in the other utilization categories. Pharmacy services consisted of outpatient prescription fills. Healthcare cost categories included total costs (medical and pharmacy costs), medical costs (inpatient admission, ED, outpatient physician office, other outpatient office, chemoimmunotherapy, radiation therapy and supportive care costs) and pharmacy costs (outpatient prescription costs).

\section{Statistical analysis}

Descriptive analyses were conducted for demographics, clinical characteristics and treatment characteristics, as well as healthcare utilization and costs. Healthcare costs and the number of visits in each setting of care were calculated as costs or visits PPPM for the duration of the follow-up period and for each individual year of follow-up. PPPM costs or utilization was calculated as costs incurred or number of services during the follow-up period, divided by the duration of follow-up care (in months) for each patient. Categorical measures were presented as counts and percentages of patients in each category, while means and standard deviations (SDs) or median and interquartile 
Patients with at least a) one inpatient claim with DLBCL; or b) two claims with DLBCL $\geq 60$ days apart, but within 1 year, between 1 January 2008 and 31 October 2015

$$
(n=6567)
$$

$<18$ years of age $(n=76)$

$<12$ months of continuous eligibility prior to index diagnosis date $(\mathrm{n}=2162)$

Evidence of chemotherapy or SCT in baseline period $(n=1521)$

Other primary cancers $(n=1004)$

Metastatic disease $(n=215)$

$<60$ days of follow-up $(n=516)$

Inconsistent data $(\mathrm{n}=41)$

Follicular or other NHL cancer $(n=236)$

SCT or SCT monotherapy as first-line treatment $(n=34)$

Preliminary DLBCL patient population $(n=2486)$

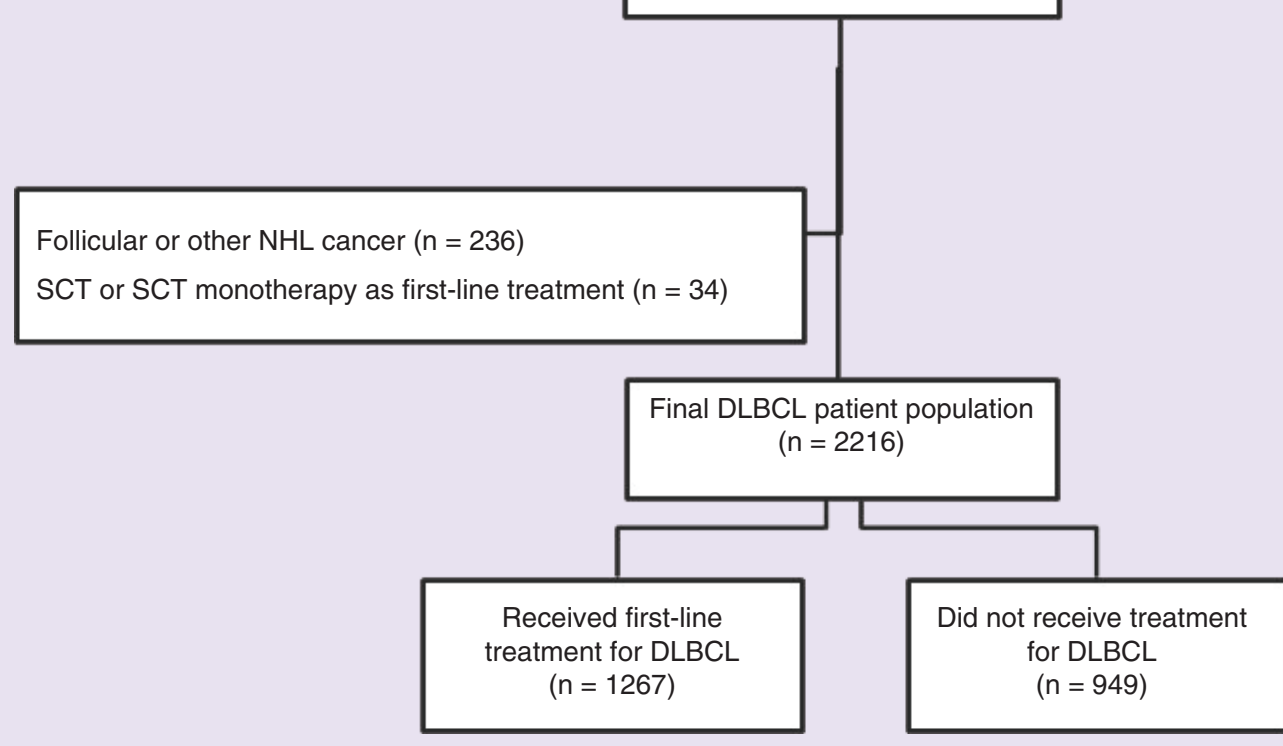

Figure 1. Sample attrition: diffuse large B-cell lymphoma.

DLBCL: Diffuse large B-cell lymphoma; NHL: Non-Hodgkin's lymphoma; SCT: Stem cell transplant.

range (IQR), as appropriate, were presented for continuous measures. All analyses were conducted using SAS $^{\circledR}$ version 9.4 (SAS Institute, NC, USA).

\section{Results}

\section{Sample description}

A total of 6567 patients with a diagnosis for DLBCL and 11,422 patients with a diagnosis of FL were identified from the Optum database during the enrollment period. After applying the study inclusion and exclusion criteria, 1267 (57.2\%) newly diagnosed DLBCL patients and 1595 (41.6\%) newly diagnosed FL patients who initiated treatment were included in this analysis (Figures $1 \& 2$, respectively).

The median age of the DLBCL cohort was 71 years and slightly over half of the patients were male (Table 1). 
Table 1. Baseline characteristics.

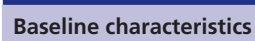

Age

Age

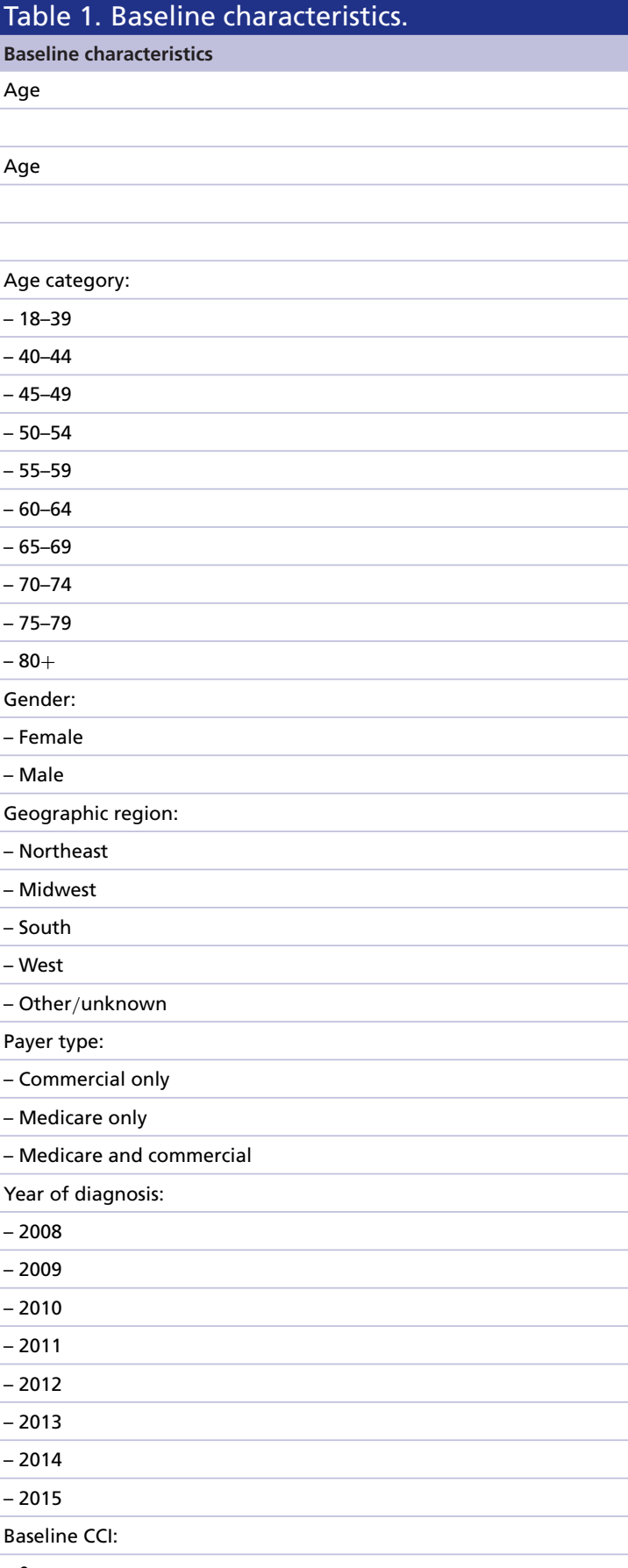

Age category:

$-18-39$

$-40-44$

$-45-49$

$-50-54$

$-55-59$

$-60-64$

$-65-69$

- 70-74

$-75-79$

$-80+$

Gender:

- Female

- Male

Geographic region:

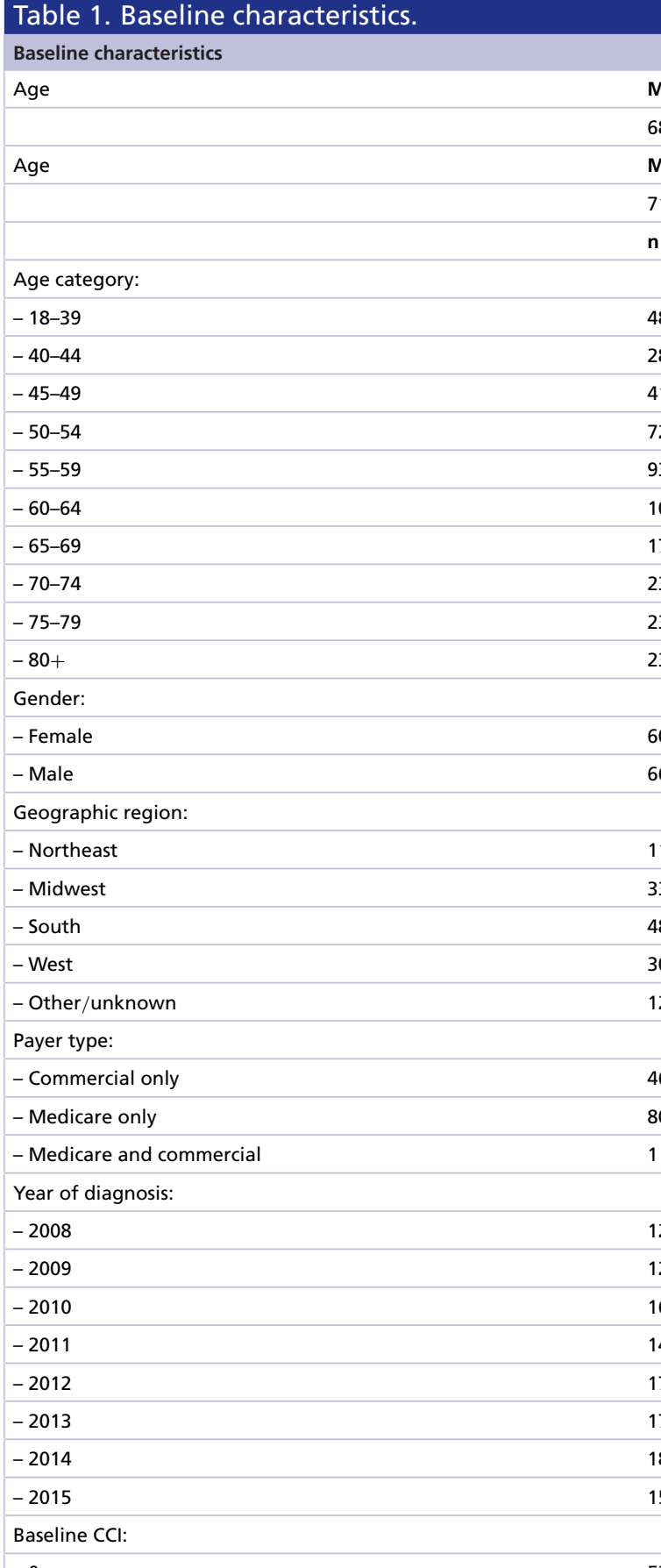

- Midwest

- South

- West

- Other/unknown

Payer type:

- Commercial only
- Medicare only
- Medicare and commercial

Year of diagnosis:

$-2008$

$-2009$

$-2010$

$-2011$

$-2012$

$-2013$

$-2014$

$-2015$

Baseline $\mathrm{CCl}$ :

$-0$

$-1$

$-2+$

Presence of each $\mathrm{CCl}$ comorbidity at baseline:

- Myocardial infarction

- Congestive heart failure

- Chronic pulmonary disease

- Peptic ulcer disease

- Peripheral vascular disease

- Mild liver disease

CCI: Charlson comorbidity index; DLBCL: Diffuse large B-cell lymphoma; FL: Follicular lymphoma; N/A: Not applicable; SD: Standard deviation.

$118 \quad 9.3 \quad 136 \quad 8.5$

$339 \quad 26.8 \quad 438 \quad 27.5$

$\begin{array}{llll}489 & 38.6 & 647 & 40.6\end{array}$

$309 \quad 24.4 \quad 355 \quad 22.3$

$\begin{array}{llll}12 & 0.9 & 19 & 1.2\end{array}$

$\begin{array}{llll}466 & 36.8 & 691 & 43.3\end{array}$

$\begin{array}{llll}800 & 63.1 & 899 & 56.4\end{array}$

$1 \quad 0.1$

$\begin{array}{llll}126 & 9.9 & 178 & 11.2\end{array}$

$\begin{array}{llll}128 & 10.1 & 204 & 12.8\end{array}$

$\begin{array}{llll}163 & 12.9 & 182 & 11.4\end{array}$

$\begin{array}{llll}147 & 11.6 & 229 & 14.4\end{array}$

$\begin{array}{llll}179 & 14.1 & 228 & 14.3\end{array}$

$\begin{array}{llll}178 & 14.0 & 251 & 15.7\end{array}$

$\begin{array}{llll}187 & 14.8 & 197 & 12.4\end{array}$

$\begin{array}{llll}159 & 12.5 & 126 & 7.9\end{array}$

$\begin{array}{llll}534 & 42.1 & 872 & 54.7\end{array}$

$\begin{array}{llll}317 & 25.0 & 345 & 21.6\end{array}$

$\begin{array}{llll}416 & 32.8 & 378 & 23.7\end{array}$

$\begin{array}{llll}51 & 4.0 & 50 & 3.1\end{array}$

$167 \quad 13.2 \quad 144 \quad 9.0$

$\begin{array}{llll}164 & 12.9 & 173 & 10.8\end{array}$

$54 \quad 4.3 \quad 17 \quad 1.1$

$\begin{array}{llll}146 & 11.5 & 146 & 9.2\end{array}$

FL patients $(n=1595)$

\begin{tabular}{ll} 
Mean & SD \\
\hline 68 & 12.7 \\
\hline Median & Range \\
\hline 69 & $18-89$ \\
$\mathbf{n}$ & $\%($ of $\mathbf{n}=\mathbf{1 5 9 5})$ \\
\hline
\end{tabular}

\begin{tabular}{ll}
51 & 3.2 \\
34 & 2.1 \\
\hline 58 & 3.6 \\
\hline 108 & 6.8 \\
148 & 9.3 \\
176 & 11.0 \\
224 & 14.0 \\
273 & 17.1 \\
219 & 13.7 \\
\hline 304 & 19.1 \\
\hline
\end{tabular}

$812 \quad 50.9$

$783 \quad 49.1$

0.3

0.3 
Table 1. Baseline characteristics (cont.).

\begin{tabular}{|c|c|c|c|c|}
\hline \multirow{2}{*}{$\begin{array}{l}\text { Baseline characteristics } \\
\text { - Moderate to severe liver disease }\end{array}$} & \multicolumn{2}{|c|}{ DLBCL patients $(n=1267)$} & \multirow{2}{*}{\multicolumn{2}{|c|}{$\begin{array}{c}\text { FL patients }(n=1595) \\
0.3\end{array}$}} \\
\hline & 8 & 0.6 & & \\
\hline - Connective tissue disease & 48 & 3.8 & 31 & 1.9 \\
\hline - Diabetes & 332 & 26.2 & 323 & 20.3 \\
\hline - Diabetes with end-organ damage & 115 & 9.1 & 122 & 7.6 \\
\hline - Dementia & 15 & 1.2 & 12 & 0.8 \\
\hline - Hemiplegia & 12 & 0.9 & 8 & 0.5 \\
\hline - Moderate to severe renal disease & 154 & 12.2 & 140 & 8.8 \\
\hline - Cerebrovascular disease & 122 & 9.6 & 113 & 7.1 \\
\hline - AIDS & 10 & 0.8 & 4 & 0.3 \\
\hline \multicolumn{5}{|l|}{ Reasons for end of follow-up: } \\
\hline - Progression to DLBCL & $\mathrm{N} / \mathrm{A}$ & $\mathrm{N} / \mathrm{A}$ & 196 & 12.3 \\
\hline - Death & 120 & 9.5 & 92 & 5.8 \\
\hline - End of eligibility & 585 & 46.2 & 654 & 41.0 \\
\hline - End of follow-up & 562 & 44.4 & 653 & 40.9 \\
\hline
\end{tabular}

In the FL cohort, the median age was 69 years and about half of the patients were male (Table 1). Medicare was the most common insurance payer in both cohorts. About $32.8 \%$ of DLBCL patients and $23.7 \%$ of FL patients had a CCI score of $\geq 2 ; 25.0 \%$ of DLBCL patients and $21.6 \%$ of FL patients had a CCI score of 1 . Of the $\mathrm{CCI}$ conditions, diabetes, congestive heart failure, chronic pulmonary disease, moderate to severe renal disease and peripheral vascular disease were the most common.

\section{DLBCL-related treatment}

DLBCL patients initiated treatment within 1 month following DLBCL diagnosis (median: 0.7 months [IQR: 0.4-1.4]). The majority of patients received only one LOT over the duration of the follow-up period (first line: 1267 patients [100\%]; second line: 159 patients [12.5\%]; and third line: 34 patients [2.7\%]) (Table 2). The median duration of therapy was 4.2 months (IQR: 2.3-4.5; range: 0.2-39.4) for the first line, 2.1 months (IQR: 1.2-3.8; range: $0.03-32.4$ ) for the second line and 3.5 months (IQR: 0.9-5.2; range: 0.7-17.3) for the third line.

Treatment regimens across the LOTs were mostly rituximab-based, with most being combination regimens. Among those who received combination therapy, rituximab, cyclophosphamide, doxorubicin, vincristine, prednisone (R-CHOP; 69.7\%) was the most common in the first-line setting, while bendamustine + rituximab was the most common in second-line $(22.3 \%)$ and third-line $(29.2 \%)$ treatment regimen. Receipt of SCT increased from $1.7 \%$ in first line to $8.8 \%$ in the third line. Use of supportive care was also common during each LOT, with granulocyte colony-stimulating factors being the most commonly used.

\section{FL-related treatment}

FL patients initiated treatment slightly over 1 month following FL diagnosis (median: 1.2 months [IQR: 0.6-3.5]). Few patients received more than 1 LOT over the duration of the follow-up period (first line: 1595 patients [100\%]; second line: 259 patients [16.2\%]; and third line: 50 patients [3.1\%]) (Table 2). The median duration of therapy was 4.5 months (IQR: 2.6-10.6; range: 0.03-78.7) for the first line, 3.5 months (IQR: 1.4-7.5; range: 0.03-34.8) for the second line and 4.5 months (IQR: 2.6-8.2; range: 0.03-42.9) for the third line.

Rituximab-based regimens dominated across all LOTs, and were mainly combination regimens. Among those who received combination therapy, bendamustine + rituximab (34.2 and 43.9\%) and R-CHOP (33.5 and 15.3\%) were the most common regimens in the first-line and second-line settings, respectively, while bendamustine + rituximab was the most common in the third-line (40.7\%) treatment regimen. Receipt of SCT increased from $0.6 \%$ in first-line to $10.0 \%$ in third-line therapy. Granulocyte colony-stimulating factors were the most commonly used supportive care treatment. 
$<18$ years of age $(n=89)$

$<12$ months of continuous care prior to index diagnosis date $(n=4824)$

Evidence of chemotherapy and/or SCT in baseline period $(\mathrm{n}=1704)$

Other primary cancer $(n=2569)$

Metastatic disease $(n=225)$

$<60$ days of follow-up $(n=706)$

Inconsistent data $(\mathrm{n}=126)$

Patients with at least a) one inpatient claim with $\mathrm{FL}$ or b) two claims with $\mathrm{FL}$ at least 60 days apart but within 1 year, between 1 January 2008 and 31 October 2015 $(n=11,422)$

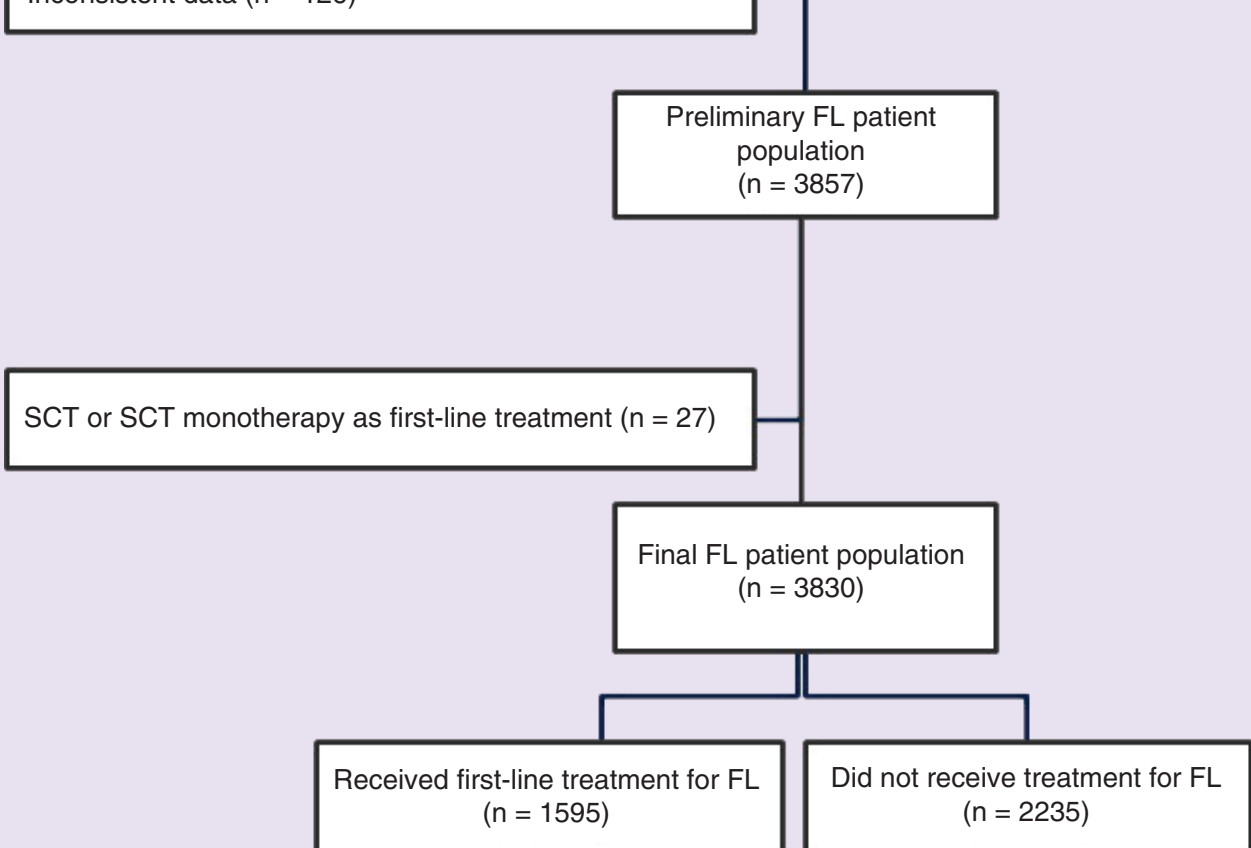

Figure 2. Sample attrition: follicular lymphoma.

FL: Follicular lymphoma; NHL: Non-Hodgkin's lymphoma; SCT: Stem cell transplant.

\section{Healthcare utilization following DLBCL \& FL diagnosis \\ Outpatient visits}

During the follow-up period, almost all DLBCL and FL patients had $\geq 1$ all-cause outpatient physician office visit and other outpatient visits (Tables $3 \& 4$ ). In the DLBCL cohort, 68.0 and $80.1 \%$ had a DLBCL-related outpatient physician office visit and other outpatient visit, respectively. DLBCL-related outpatient physician visits and other outpatient visits were a mean of 1.43 (SD: 2.48) and 0.77 (SD: 1.26) visits PPPM, respectively. In the FL cohort, 74.3 and $83.4 \%$ had an FL-related outpatient physician office visit and other outpatient visits, respectively. FL-related outpatient physician visits and other outpatient visits were a mean of 1.21 (SD: 2.04) and 0.71 (SD: 1.32) visits PPPM, respectively. The proportion of patients with $\geq 1$ outpatient physician visit or other outpatient visit, and the number of visits in each setting of care decreased from year 1 to 2 following DLBCL and FL diagnosis. 


\begin{tabular}{|c|c|c|c|c|}
\hline \multirow[t]{2}{*}{ Variables } & \multicolumn{2}{|c|}{ DLBCL patients } & \multicolumn{2}{|c|}{ FL patients } \\
\hline & $\mathrm{n}$ & $\%($ of $n$ ) & $\mathrm{n}$ & $\%($ of $n)$ \\
\hline 1LT & 1267 & $\%$ (of $n=1267$ ) & 1595 & $\%($ of $n=1595)$ \\
\hline Monotherapy: & 156 & 12.3 & 502 & 31.5 \\
\hline - Rituximab & 104 & 8.2 & 418 & 26.2 \\
\hline - Other & 52 & 4.1 & 84 & 5.3 \\
\hline Combination therapy: & 1111 & 87.7 & 1093 & 68.5 \\
\hline - Rituximab-based & 1059 & 83.6 & 1059 & 66.4 \\
\hline - Nonrituximab-based & 52 & 4.1 & 34 & 2.1 \\
\hline $\mathrm{SCT}$ (at any point during 1LT) & 21 & 1.7 & 10 & 0.6 \\
\hline Receipt of supportive care during $1 \mathrm{LT}$ & 1141 & 90.1 & 1119 & 70.2 \\
\hline Duration of therapy: & Median & IQR & Median & IQR \\
\hline - Duration of $1 \mathrm{LT}$, months & 4.2 & $2.3,4.5$ & 4.5 & $2.6,10.6$ \\
\hline 2LT & 159 & $\%($ of $n=159$ ) & 259 & $\%($ of $n=259$ ) \\
\hline Monotherapy: & 47 & 29.6 & 102 & 39.4 \\
\hline - Rituximab & 20 & 12.6 & 71 & 27.4 \\
\hline - Other & 27 & 16.9 & 31 & 12.0 \\
\hline Combination therapy: & 112 & 70.4 & 157 & 60.6 \\
\hline - Rituximab-based & 92 & 57.9 & 149 & 57.5 \\
\hline - Nonrituximab-based & 20 & 12.6 & 8 & 3.1 \\
\hline $\mathrm{SCT}$ (at any point during 2LT) & 13 & 8.2 & 7 & 2.7 \\
\hline Receipt of supportive care during $2 \mathrm{LT}$ & 120 & 75.5 & 151 & 58.3 \\
\hline Duration of therapy: & Median & IQR & Median & IQR \\
\hline - Duration of $2 \mathrm{LT}$, months & 2.1 & $1.2,3.8$ & 3.5 & $1.4,7.5$ \\
\hline 3LT & 34 & $\%$ (of $n=34$ ) & 50 & $\%($ of $n=50$ ) \\
\hline Monotherapy: & 10 & 29.4 & 23 & 46.0 \\
\hline - Rituximab & 2 & 5.9 & 14 & 28.0 \\
\hline - Nonrituximab-based & 8 & 23.5 & 8 & 18.0 \\
\hline Combination therapy: & 24 & 70.6 & 27 & 54.0 \\
\hline - Rituximab-based & 13 & 38.2 & 26 & 52.0 \\
\hline - Nonrituximab-based & 11 & 32.4 & 1 & 2.0 \\
\hline $\mathrm{SCT}$ (at any point during $3 \mathrm{LT}$ ) & 3 & 8.8 & 5 & 10.0 \\
\hline Receipt of supportive care during $3 \mathrm{LT}$ & 31 & 91.2 & 36 & 72.0 \\
\hline Duration of therapy: & Median & IQR & Median & IQR \\
\hline - Duration of $3 \mathrm{LT}$, months & 3.5 & $0.9-5.2$ & 4.5 & $2.6-8.2$ \\
\hline
\end{tabular}

\section{Inpatient admissions}

Overall, inpatient admissions were common during the follow-up period, with $65.8 \%$ of DLBCL patients having $\geq 1$ inpatient admission, with a mean of 0.18 (SD: 0.37) inpatient admissions PPPM, and a mean 1.31 (SD: 3.04 ) inpatient days PPPM (Table 3). In the FL cohort, $51.0 \%$ of FL patients had $\geq 1$ inpatient admission, with a mean of 0.11 (SD: 0.30) inpatient admissions PPPM, and a mean 0.75 (SD: 2.27) inpatient days PPPM (Table 4). However, inpatient admissions associated with DLBCL and FL were less common. The rate of inpatient admissions, number of inpatient admissions and length of stay decreased from year 1 to 2 following DLBCL and FL diagnosis.

\section{ED visits}

Over half of the DLBCL and FL patients had $\geq 1 \mathrm{ED}$ visit during the entire follow-up period (DLBCL: 60.0\% and FL: $57.2 \%$ ), with a mean of $0.22(0.48)$ and $0.19(0.44)$ visits PPPM, respectively (Tables 3 \& 4). DLBCL- and FL-related ED visits were low, occurring in 3.2\% of DLBCL patients, with a mean of 0.01 (SD: 0.06 ) and in $4.0 \%$ 


\begin{tabular}{|c|c|c|c|c|c|c|}
\hline \multirow[t]{2}{*}{ Healthcare utilization ${ }^{\dagger}$} & \multicolumn{2}{|c|}{ Overall $(n=1267)$} & \multicolumn{2}{|c|}{ Year $1(n=1267)$} & \multicolumn{2}{|c|}{ Year $2(n=830)$} \\
\hline & $\mathbf{n}$ & $\%$ & $\mathrm{n}$ & $\%$ & $\mathrm{n}$ & $\%$ \\
\hline Inpatient visits $(\geq 1)$, all-cause: & 836 & 66.0 & 730 & 57.6 & 174 & 21.0 \\
\hline - DLBCL-related & 158 & 12.5 & 149 & 11.8 & 9 & 1.1 \\
\hline - Non-DLBCL-related & 802 & 63.3 & 688 & 54.3 & 173 & 20.8 \\
\hline ED visits $(\geq 1)$, all-cause: & 760 & 60.0 & 616 & 48.6 & 221 & 26.6 \\
\hline - DLBCL-related & 40 & 3.2 & 40 & 3.2 & 1 & 0.1 \\
\hline - Non-DLBCL-related & 751 & 59.3 & 605 & 47.8 & 220 & 26.5 \\
\hline Physician office visits ( $\geq 1$ ), all-cause: & 1171 & 92.4 & 1159 & 91.5 & 688 & 82.9 \\
\hline - DLBCL-related & 861 & 68.0 & 828 & 65.4 & 381 & 45.9 \\
\hline - Non-DLBCL-related & 1161 & 91.6 & 1148 & 90.6 & 678 & 81.7 \\
\hline Other outpatient visits ( $\geq 1$ ), all-cause: & 1262 & 99.6 & 1260 & 99.4 & 753 & 90.7 \\
\hline - DLBCL-related & 1015 & 80.1 & 968 & 76.4 & 374 & 45.1 \\
\hline - Non-DLBCL-related & 1261 & 99.5 & 1259 & 99.4 & 741 & 89.3 \\
\hline \multicolumn{7}{|l|}{ DLBCL treatment visits $(\geq 1)$ : } \\
\hline - Medical chemoimmunotherapy & 1253 & 98.9 & 1229 & 97.0 & 155 & 18.7 \\
\hline - Medical supportive care & 1065 & 84.1 & 1047 & 82.6 & 99 & 11.9 \\
\hline \multicolumn{7}{|c|}{ Outpatient pharmacy prescription fills $(\geq 1)$, all-cause: } \\
\hline - Chemoimmunotherapy & 1013 & 80.0 & 987 & 77.9 & 112 & 13.5 \\
\hline - Supportive care & 905 & 71.4 & 816 & 64.4 & 314 & 37.8 \\
\hline \multirow[t]{2}{*}{ - Non-DLBCL-related } & 1144 & 90.3 & 1136 & 89.7 & 658 & 79.3 \\
\hline & Mean & SD & Mean & SD & Mean & SD \\
\hline Inpatient visits (PPPM), all-cause: & 0.18 & 0.37 & 0.20 & 0.38 & 0.09 & 0.59 \\
\hline - DLBCL-related & 0.01 & 0.05 & 0.02 & 0.06 & 0.00 & 0.03 \\
\hline - Non-DLBCL-related & 0.16 & 0.36 & 0.18 & 0.37 & 0.09 & 0.58 \\
\hline ED visits (PPPM), all-cause: & 0.22 & 0.48 & 0.23 & 0.49 & 0.12 & 0.38 \\
\hline - DLBCL-related & 0.01 & 0.06 & 0.01 & 0.06 & 0.00 & 0.01 \\
\hline - Non-DLBCL-related & 0.22 & 0.46 & 0.22 & 0.46 & 0.12 & 0.38 \\
\hline Physician office visits (PPPM), all-cause: & 3.83 & 3.65 & 4.70 & 3.94 & 1.92 & 2.30 \\
\hline - DLBCL-related & 1.43 & 2.48 & 1.89 & 2.81 & 0.40 & 0.99 \\
\hline - Non-DLBCL-related & 2.41 & 2.58 & 2.81 & 2.87 & 1.52 & 1.95 \\
\hline Other outpatient visits (PPPM), all-cause: & 4.67 & 4.67 & 5.48 & 4.83 & 2.44 & 3.45 \\
\hline - DLBCL-related & 0.77 & 1.26 & 0.99 & 1.48 & 0.25 & 0.61 \\
\hline - Non-DLBCL-related & 3.90 & 4.22 & 4.49 & 4.38 & 2.19 & 3.29 \\
\hline \multicolumn{7}{|l|}{ DLBCL treatment visits (PPPM): } \\
\hline - Medical chemoimmunotherapy & 1.27 & 1.43 & 1.68 & 1.41 & 0.20 & 0.75 \\
\hline - Medical supportive care & 0.47 & 0.64 & 0.64 & 0.75 & 0.09 & 0.47 \\
\hline \multicolumn{7}{|c|}{ Outpatient pharmacy prescription fills (PPPM), all-cause: } \\
\hline - Chemoimmunotherapy & 0.28 & 0.35 & 0.36 & 0.35 & 0.05 & 0.20 \\
\hline - Supportive care & 0.30 & 0.47 & 0.34 & 0.50 & 0.20 & 0.43 \\
\hline - Non-DLBCL-related & 1.79 & 1.41 & 1.91 & 1.43 & 1.38 & 1.41 \\
\hline
\end{tabular}

${ }^{\dagger}$ DLBCL-related and non-DLBCL-related are not mutually exclusive groups; patients could be in both categories, and percentages are relative to the overall ' $n$ ' in the column as the denominator

DLBCL: Diffuse large B-cell lymphoma; ED: Emergency department; PPPM: Per-patient per-month; SD: Standard deviation.

of FL patients, with a mean of 0.01 (SD: 0.15). The proportion of patients with $\geq 1 \mathrm{ED}$ visit and the number of ED visits decreased from year 1 to 2 following DLBCL and FL diagnosis. 
Table 4. Healthcare utilization overall and during year 1 and 2 postindex date for treated follicular lymphoma

\section{patients.}

\begin{tabular}{|c|c|c|c|c|c|c|}
\hline \multirow[t]{2}{*}{ Proportion of patients with healthcare utilization ${ }^{\dagger}$} & \multicolumn{2}{|c|}{ Overall $(n=1595)$} & \multicolumn{2}{|c|}{ Year $1(n=1595)$} & \multicolumn{2}{|c|}{ Year $2(n=1165)$} \\
\hline & $\mathrm{n}$ & $\%$ & $\mathrm{n}$ & $\%$ & $\mathrm{n}$ & $\%$ \\
\hline Inpatient visits $(\geq 1)$, all-cause: & 813 & 51.0 & 614 & 38.5 & 235 & 20.2 \\
\hline - FL-related & 153 & 9.6 & 135 & 8.5 & 16 & 1.4 \\
\hline - Non-FL-related & 760 & 47.6 & 544 & 34.1 & 232 & 19.9 \\
\hline ED visits ( $\geq 1$ ), all-cause: & 913 & 57.2 & 651 & 40.8 & 349 & 30.0 \\
\hline - FL-related & 64 & 4.0 & 52 & 3.3 & 10 & 0.9 \\
\hline - Non-FL-related & 904 & 56.7 & 638 & 40.0 & 345 & 29.6 \\
\hline Physician office visits $(\geq 1)$, all-cause: & 1469 & 92.1 & 1451 & 91.0 & 990 & 85.0 \\
\hline - FL-related & 1185 & 74.3 & 1149 & 72.0 & 612 & 52.5 \\
\hline - Non-FL-related & 1459 & 91.5 & 1439 & 90.2 & 977 & 83.9 \\
\hline Other outpatient visits $(\geq 1)$, all-cause: & 1585 & 99.4 & 1580 & 99.1 & 1,073 & 92.1 \\
\hline - FL-related & 1331 & 83.4 & 1272 & 79.7 & 557 & 47.8 \\
\hline - Non-FL-related & 1584 & 99.3 & 1574 & 98.7 & 1058 & 90.8 \\
\hline \multicolumn{7}{|l|}{ FL treatment visits $(\geq 1)$ : } \\
\hline - Medical chemoimmunotherapy & 1571 & 98.5 & 1439 & 90.2 & 581 & 49.9 \\
\hline - Medical supportive care & 940 & 58.9 & 832 & 52.2 & 149 & 12.8 \\
\hline \multicolumn{7}{|l|}{ Outpatient pharmacy prescription fills ( $\geq 1)$, all-cause: } \\
\hline - Chemoimmunotherapy & 963 & 60.4 & 816 & 51.2 & 199 & 17.1 \\
\hline - Supportive care & 1121 & 70.3 & 1000 & 62.7 & 485 & 41.6 \\
\hline \multirow[t]{2}{*}{ - Non-FL-related } & 1451 & 91.0 & 1430 & 89.7 & 957 & 82.1 \\
\hline & Mean & SD & Mean & SD & Mean & SD \\
\hline Inpatient visits (PPPM), all-cause: & 0.11 & 0.30 & 0.11 & 0.30 & 0.06 & 0.20 \\
\hline - FL-related & 0.01 & 0.13 & 0.01 & 0.14 & 0.00 & 0.03 \\
\hline - Non-FL-related & 0.10 & 0.26 & 0.10 & 0.26 & 0.05 & 0.19 \\
\hline ED visits (PPPM), all-cause: & 0.19 & 0.44 & 0.19 & 0.46 & 0.14 & 0.43 \\
\hline - FL-related & 0.01 & 0.15 & 0.01 & 0.17 & 0.01 & 0.13 \\
\hline - Non-FL-related & 0.18 & 0.40 & 0.18 & 0.41 & 0.13 & 0.39 \\
\hline Physician office visits (PPPM), all-cause: & 3.62 & 3.48 & 4.31 & 3.70 & 2.16 & 2.29 \\
\hline - FL-related & 1.21 & 2.04 & 1.57 & 2.28 & 0.53 & 1.05 \\
\hline - Non-FL-related & 2.41 & 2.66 & 2.74 & 2.91 & 1.62 & 1.96 \\
\hline Other outpatient visits (PPPM), all-cause: & 3.87 & 5.11 & 4.39 & 5.22 & 2.44 & 3.41 \\
\hline - FL-related & 0.71 & 1.32 & 0.89 & 1.45 & 0.33 & 0.82 \\
\hline - Non-FL-related & 3.16 & 4.41 & 3.49 & 4.50 & 2.11 & 3.22 \\
\hline \multicolumn{7}{|l|}{ FL treatment visits (PPPM): } \\
\hline - Medical chemoimmunotherapy & 1.23 & 1.70 & 1.58 & 1.75 & 0.44 & 0.68 \\
\hline - Medical supportive care & 0.29 & 0.64 & 0.39 & 0.81 & 0.07 & 0.41 \\
\hline \multicolumn{7}{|l|}{ Outpatient pharmacy prescription fills (PPPM), all-cause: } \\
\hline - Chemoimmunotherapy & 0.17 & 0.34 & 0.22 & 0.36 & 0.05 & 0.17 \\
\hline - Supportive care & 0.25 & 0.41 & 0.28 & 0.43 & 0.20 & 0.40 \\
\hline - Non-FL-related & 1.68 & 1.35 & 1.74 & 1.38 & 1.41 & 1.33 \\
\hline
\end{tabular}

Chemoimmunotherapy \& supportive care visits

All patients received chemoimmunotherapy during the follow-up period; $98.9 \%$ of DLBCL patients and $98.5 \%$ of FL patients had $\geq 1$ inpatient or outpatient chemoimmunotherapy visit, and $84.1 \%$ of DLBCL patients and $58.9 \%$ of FL patients had $\geq 1$ inpatient or outpatient supportive care visit (Tables $3 \& 4$ ). DLBCL patients had a mean of 1.27 (SD: 1.43) chemoimmunotherapy-related visits PPPM and 0.47 (SD: 0.64) supportive care visits 
PPPM, while FL patients had a mean of 1.23 (SD: 1.70) chemoimmunotherapy-related visits PPPM and 0.29 (SD: 0.64) supportive care visits PPPM.

In the outpatient pharmacy setting, $80.0 \%$ of DLBCL patients and $60.4 \%$ of FL patients had $\geq 1$ prescription fill for chemoimmunotherapy, and $71.4 \%$ of DLBCL patients and $70.3 \%$ of FL patients had $\geq 1$ prescription fill for supportive care agent (Tables $3 \& 4$ ). DLBCL patients had a mean of 0.28 (SD: 0.35 ) chemoimmunotherapy prescription fills PPPM and 0.30 (SD: 0.47) supportive care prescription fills PPPM, while FL patients had a mean of 0.17 (SD: 0.34) chemoimmunotherapy prescription fills PPPM and 0.25 (SD: 0.41) supportive care prescription fills PPPM. The chemoimmunotherapy and supportive care utilization also decreased from year 1 to 2 following DLBCL and FL diagnosis.

\section{Healthcare costs following DLBCL \& FL diagnosis}

Over the entire follow-up period, treated DLBCL patients had a total cost of US $\$ 11,890$ (SD: US\$11,515) PPPM; of which, US\$6691 (SD: US\$6593) was deemed DLBCL-related and US\$5199 (SD: US\$7283) was deemed non-DLBCL-related (Table 5). For FL patients, total PPPM cost was US\$10,460 (SD: US\$13,871); of which, US\$6482 (SD: US\$10,341) was FL-related and US\$3978 (SD: US\$6867) was non-FL-related (Table 6). For both DLBCL and FL patients, costs were higher in year 1 than in year 2 following diagnosis.

The majority of overall costs of care were composed of medical costs, with a mean of medical cost of US $\$ 11,487$ (SD: US\$1 1,303) PPPM for DLBCL patients and US\$10,147 (SD: US\$13,755) PPPM for FL patients. Between year 1 and 2 following a DLBCL and FL diagnosis, PPPM medical costs decreased. DLBCL-related medical costs made up almost $57 \%$ of the mean medical costs in the DLBCL cohort, at an average of US\$6532 (SD: US $\$ 6457$ ) PPPM across the follow-up period, while FL-related medical costs made up almost $63 \%$ of mean medical costs in the FL cohort, at an average of US $\$ 6390$ (SD: US $\$ 10,308$ ) PPPM across the follow-up period.

In the DLBCL cohort, mean DLBCL-related medical costs constituted almost $59.6 \%$ of total mean DLBCLrelated medical costs in year 1 (US\$8327 PPPM [SD: US\$5925]), and this decreased to 37\% (US\$1443 PPPM [SD: US \$4349] PPPM) in year 2. In the FL cohort, FL-related costs constituted almost $65 \%$ of mean medical costs in year 1 (US\$7766 PPPM [SD: US $\$ 10,217]$ ), and this decreased to 55\% (US\$2670 PPPM [SD: US\$5488]) in year 2. The primary drivers of DLBCL-related and FL-related medical costs were chemoimmunotherapy and supportive care costs, and these costs also decreased from year 1 to 2 following diagnosis.

Non-DLBCL-related medical costs made up about $43 \%$ of the mean total all-cause medical costs in the DLBCL cohort (US\$4955 PPPM [SD: US\$7210]); while in the FL cohort, non-FL-related medical costs made up about $37 \%$ of mean total all-cause medical costs (US $\$ 3757$ PPPM [SD: US $\$ 6793]$ ). Both costs decreased between year 1 and 2 following diagnosis. The primary contributors to non-DLBCL-related and non-FL-related medical costs were inpatient admissions and other outpatient services.

\section{Discussion}

In this retrospective study, claims data were used to assess the healthcare utilization and costs of newly diagnosed DLBCL and FL patients who were treated. These outcomes have not been extensively studied in the USA. The results of our analyses showed that the healthcare burden associated with treating DLBCL and FL is considerable, especially in the first year following diagnosis. The total PPPM costs of treated DLBCL and FL patients over the duration of follow-up were US $\$ 11,890$ and US $\$ 10,460$, respectively, with the majority of the costs incurred in the first year following diagnosis. In the first year following DLBCL and FL diagnosis, the total PPPM costs were US $\$ 14,402$ and US $\$ 12,183$, respectively, and by the second year, costs decreased to US $\$ 4190$ and US $\$ 5062$, respectively. The decrease in costs between the first and second year in both cohorts was mainly driven by the decrease in chemoimmunotherapy-related medical services, followed by inpatient admissions and nonphysician office outpatient services.

The observed decrease in the chemoimmunotherapy administration costs aligns with the treatment information for DLBCL and FL cohorts. All patients in both the DLBCL and FL cohorts received a first-line therapy, which had a median duration of 4.2 and 4.5 months, respectively. However, only 12\% of DLBCL patients and 16\% of FL patients proceeded to receive a second-line therapy, and an even smaller proportion (DLBCL: $2 \%$ and FL: $3 \%)$ received a third-line therapy. This observed trend was also reported by another study using claims data from 1999 to 2000. Kutikova and colleagues reported that in patients with aggressive NHL, the adjusted mean monthly initial treatment phase costs (US\$10,970) were higher than costs incurred during secondary phase (US\$3302) [11]. Additionally, in this study, the adjusted mean monthly costs were also compared with controls without NHL; 
Table 5. Healthcare costs overall and during year 1 and 2 postindex date for treated diffuse large B-cell lymphoma patients.

\begin{tabular}{|c|c|c|c|c|c|c|}
\hline \multirow[t]{2}{*}{ Cost, 2015 US $\$$ in PPPM } & \multicolumn{2}{|c|}{ Overall $(n=931)$} & \multicolumn{2}{|c|}{ Year $1(n=931)$} & \multicolumn{2}{|c|}{ Year $2(n=586)$} \\
\hline & Mean (SD) & Median (IQR) & Mean (SD) & Median (IQR) & Mean (SD) & Median (IQR) \\
\hline Total, all-cause: & $\begin{array}{l}\text { US } \$ 11,890 \\
\text { (US } \$ 11,515 \text { ) }\end{array}$ & $\begin{array}{l}\text { US } \$ 8162 \\
\text { (US } \$ 4282 \text {-US } \$ 16,212 \text { ) }\end{array}$ & $\begin{array}{l}\text { US } \$ 14,402 \\
\text { (US } \$ 10,951)\end{array}$ & $\begin{array}{l}\text { US } \$ 11,167 \\
\text { (US } \$ 7829-\text { US } \$ 17,622 \text { ) }\end{array}$ & $\begin{array}{l}\text { US } \$ 4190 \\
\text { (US } \$ 8076 \text { ) }\end{array}$ & $\begin{array}{l}\text { US } \$ 1158 \\
\text { (US } \$ 524-U S \$ 3891)\end{array}$ \\
\hline - DLBCL-related & $\begin{array}{l}\text { US } \$ 6691 \\
\text { (US } \$ 6593)\end{array}$ & $\begin{array}{l}\text { US } \$ 4523 \\
\text { (US } \$ 2063-\text { US } \$ 9408 \text { ) }\end{array}$ & $\begin{array}{l}\text { US } \$ 8498 \\
\text { (US } \$ 6061)\end{array}$ & $\begin{array}{l}\text { US } \$ 6725 \\
\text { (US } \$ 5058-\text { US } \$ 10,422 \text { ) }\end{array}$ & $\begin{array}{l}\text { US } \$ 1528 \\
\text { (US } \$ 4538)\end{array}$ & $\begin{array}{l}\text { US } \$ 68 \\
\text { (US } \$ 2-\text { US } \$ 719)\end{array}$ \\
\hline - Non-DLBCL-related & $\begin{array}{l}\text { US } \$ 5199 \\
\text { (US } \$ 7283)\end{array}$ & $\begin{array}{l}\text { US } \$ 2802 \\
\text { (US } \$ 1363-U S \$ 5929)\end{array}$ & $\begin{array}{l}\text { US } \$ 5903 \\
\text { (US } \$ 7539)\end{array}$ & $\begin{array}{l}\text { US } \$ 3652 \\
\text { (US } \$ 1825-\text { US } \$ 6762 \text { ) }\end{array}$ & $\begin{array}{l}\text { US } \$ 2663 \\
\text { (US } \$ 5561)\end{array}$ & $\begin{array}{l}\text { US } \$ 829 \\
\text { (US } \$ 372-U S \$ 2303 \text { ) }\end{array}$ \\
\hline Medical, all-cause: & $\begin{array}{l}\text { US } \$ 11,487 \\
\text { (US } \$ 11,303)\end{array}$ & $\begin{array}{l}\text { US } \$ 7879 \\
\text { (US } \$ 3970-\text { US } \$ 15,743 \text { ) }\end{array}$ & $\begin{array}{l}\text { US } \$ 13,967 \\
\text { (US } \$ 10,717 \text { ) }\end{array}$ & $\begin{array}{l}\text { US } \$ 10,819 \\
\text { (US } \$ 7632-\text { US } \$ 17,141)\end{array}$ & $\begin{array}{l}\text { US } \$ 3890 \\
\text { (US } \$ 7819)\end{array}$ & $\begin{array}{l}\text { US } \$ 970 \\
\text { (US } \$ 419-U S \$ 3666 \text { ) }\end{array}$ \\
\hline - DLBCL-related & $\begin{array}{l}\text { US } \$ 6532 \\
\text { (US } \$ 6457)\end{array}$ & $\begin{array}{l}\text { US } \$ 4389 \\
\text { (US } \$ 2023-U S \$ 9242 \text { ) }\end{array}$ & $\begin{array}{l}\text { US } \$ 8327 \\
\text { (US } \$ 5925)\end{array}$ & $\begin{array}{l}\text { US } \$ 6637 \\
\text { (US } \$ 5016-\text { US } \$ 10,234 \text { ) }\end{array}$ & $\begin{array}{l}\text { US } \$ 1443 \\
\text { (US } \$ 4349)\end{array}$ & $\begin{array}{l}\text { US } \$ 53 \\
\text { (US } \$ 0-\text { US } \$ 581 \text { ) }\end{array}$ \\
\hline - Non-DLBCL-related & $\begin{array}{l}\text { US } \$ 4955 \\
\text { (US } \$ 7210)\end{array}$ & $\begin{array}{l}\text { US } \$ 2573 \\
\text { (US } \$ 1226-\text { US } \$ 5427 \text { ) }\end{array}$ & $\begin{array}{l}\text { US } \$ 5640 \\
\text { (US } \$ 7468)\end{array}$ & $\begin{array}{l}\text { US } \$ 3378 \\
\text { (US\$1644-US\$6269) }\end{array}$ & $\begin{array}{l}\text { US } \$ 2447 \\
\text { (US } \$ 5456)\end{array}$ & $\begin{array}{l}\text { US } \$ 672 \\
\text { (US } \$ 290-U S \$ 1960)\end{array}$ \\
\hline Pharmacy, all-cause & $\begin{array}{l}\text { US } \$ 403 \\
\text { (US } \$ 1220)\end{array}$ & $\begin{array}{l}\text { US } \$ 137 \\
\text { (US\$30-US\$370) }\end{array}$ & $\begin{array}{l}\text { US } \$ 435 \\
\text { (US } \$ 1253)\end{array}$ & $\begin{array}{l}\text { US } \$ 145 \\
\text { (US } \$ 32-\text { US } \$ 380 \text { ) }\end{array}$ & $\begin{array}{l}\text { US } \$ 300 \\
\text { (US\$794) }\end{array}$ & $\begin{array}{l}\text { US } \$ 58 \\
\text { (US } \$ 2-\text { US } \$ 230 \text { ) }\end{array}$ \\
\hline \multicolumn{7}{|l|}{ Medical cost components } \\
\hline Inpatient, all-cause: & $\begin{array}{l}\text { US } \$ 2690 \\
\text { (US } \$ 6629)\end{array}$ & $\begin{array}{l}\text { US } \$ 442 \\
\text { (US } \$ 0-U S \$ 2249 \text { ) }\end{array}$ & $\begin{array}{l}\text { US } \$ 2976 \\
\text { (US } \$ 6839)\end{array}$ & $\begin{array}{l}\text { US } \$ 540 \\
\text { (US } \$ 0 \text {-US } \$ 2755 \text { ) }\end{array}$ & $\begin{array}{l}\text { US } \$ 1012 \\
\text { (US } \$ 4221)\end{array}$ & $\begin{array}{l}\text { US } \$ 0 \\
\text { (US\$0-US } \$ 0 \text { ) }\end{array}$ \\
\hline - DLBCL-related & $\begin{array}{l}\text { US } \$ 282 \\
\text { (US } \$ 2018)\end{array}$ & $\begin{array}{l}\text { US } \$ 0 \\
\text { (US } \$ 0-\text { US } \$ 25 \text { ) }\end{array}$ & $\begin{array}{l}\text { US } \$ 332 \\
\text { (US } \$ 2081)\end{array}$ & $\begin{array}{l}\text { US } \$ 0 \\
\text { (US } \$ 0-\text { US } \$ 45)\end{array}$ & $\begin{array}{l}\text { US } \$ 8 \\
\text { (US } \$ 670)\end{array}$ & $\begin{array}{l}\text { US } \$ 0 \\
\text { (US } \$ 0-U S \$ 0 \text { ) }\end{array}$ \\
\hline - Non-DLBCL-related & $\begin{array}{l}\text { US } \$ 2408 \\
\text { (US } \$ 5957)\end{array}$ & $\begin{array}{l}\text { US } \$ 384 \\
\text { (US } \$ 0-\text { US } \$ 2025 \text { ) }\end{array}$ & $\begin{array}{l}\text { US } \$ 2645 \\
\text { (US } \$ 6183)\end{array}$ & $\begin{array}{l}\text { US } \$ 430 \\
\text { (US } \$ 0-\text { US } \$ 2349 \text { ) }\end{array}$ & $\begin{array}{l}\text { US } \$ 1003 \\
\text { (US } \$ 4202)\end{array}$ & $\begin{array}{l}\text { US } \$ 0 \\
\text { (US } \$ 0-\text { US } \$ 0 \text { ) }\end{array}$ \\
\hline ED, all-cause: & $\begin{array}{l}\text { US } \$ 199 \\
\text { (US\$407) }\end{array}$ & $\begin{array}{l}\text { US } \$ 40 \\
\text { (US } \$ 0 \text {-US } \$ 232 \text { ) }\end{array}$ & $\begin{array}{l}\text { US } \$ 209 \\
\text { (US } \$ 414 \text { ) }\end{array}$ & $\begin{array}{l}\text { US } \$ 6 \\
\text { (US } \$ 0-\text { US } \$ 259 \text { ) }\end{array}$ & $\begin{array}{l}\text { US } \$ 99 \\
\text { (US\$346) }\end{array}$ & $\begin{array}{l}\text { US } \$ 0 \\
\text { (US } \$ 0 \text {-US } \$ 8 \text { ) }\end{array}$ \\
\hline - DLBCL-related & $\begin{array}{l}\text { US } \$ 4 \\
\text { (US } \$ 48)\end{array}$ & $\begin{array}{l}\text { US } \$ 0 \\
\text { (US } \$ 0-U S \$ 0)\end{array}$ & $\begin{array}{l}\text { US } \$ 5 \\
\text { (US } \$ 53)\end{array}$ & $\begin{array}{l}\text { US } \$ 0 \\
\text { (US } \$ 0-U S \$ 0)\end{array}$ & $\begin{array}{l}\text { US } \$ 0 \\
\text { (US } \$ 0)\end{array}$ & $\begin{array}{l}\text { US } \$ 0 \\
\text { (US } \$ 0-U S \$ 0)\end{array}$ \\
\hline - Non-DLBCL-related & $\begin{array}{l}\text { US } \$ 194 \\
\text { (US } \$ 403)\end{array}$ & $\begin{array}{l}\text { US } \$ 39 \\
\text { (US } \$ 0-\text { US } \$ 229 \text { ) }\end{array}$ & $\begin{array}{l}\text { US } \$ 204 \\
\text { (US } \$ 408)\end{array}$ & $\begin{array}{l}\text { US } \$ 2 \\
\text { (US } \$ 0-\text { US } \$ 250 \text { ) }\end{array}$ & $\begin{array}{l}\text { US } \$ 99 \\
\text { (US\$346) }\end{array}$ & $\begin{array}{l}\text { US } \$ 0 \\
\text { (US\$0-US } \$ 8 \text { ) }\end{array}$ \\
\hline Physician office, all-cause: & $\begin{array}{l}\text { US } \$ 739 \\
\text { (US } \$ 823 \text { ) }\end{array}$ & $\begin{array}{l}\text { US } \$ 495 \\
\text { (US } \$ 258-\text { US } \$ 896)\end{array}$ & $\begin{array}{l}\text { US } \$ 917 \\
\text { (US } \$ 903 \text { ) }\end{array}$ & $\begin{array}{l}\text { US } \$ 712 \\
\text { (US } \$ 367-U S \$ 1188 \text { ) }\end{array}$ & $\begin{array}{l}\text { US } \$ 345 \\
\text { (US\$528) }\end{array}$ & $\begin{array}{l}\text { US } \$ 205 \\
\text { (US } \$ 82-\text { US } \$ 437 \text { ) }\end{array}$ \\
\hline - DLBCL-related & $\begin{array}{l}\text { US } \$ 294 \\
\text { (US } \$ 543)\end{array}$ & $\begin{array}{l}\text { US } \$ 93 \\
\text { (US } \$ 0-\text { US } \$ 347 \text { ) }\end{array}$ & $\begin{array}{l}\text { US } \$ 385 \\
\text { (US } \$ 629)\end{array}$ & $\begin{array}{l}\text { US } \$ 173 \\
\text { (US } \$ 0-\text { US } \$ 520 \text { ) }\end{array}$ & $\begin{array}{l}\text { US } \$ 73 \\
\text { (US } \$ 188)\end{array}$ & $\begin{array}{l}\text { US } \$ 7 \\
\text { (US } \$ 0-\text { US } \$ 45 \text { ) }\end{array}$ \\
\hline - Non-DLBCL-related & $\begin{array}{l}\text { US } \$ 445 \\
\text { (US } \$ 535)\end{array}$ & $\begin{array}{l}\text { US } \$ 286 \\
\text { (US } \$ 131-\text { US } \$ 560)\end{array}$ & $\begin{array}{l}\text { US } \$ 532 \\
\text { (US } \$ 613)\end{array}$ & $\begin{array}{l}\text { US } \$ 348 \\
\text { (US } \$ 139-\text { US } \$ 725 \text { ) }\end{array}$ & $\begin{array}{l}\text { US } \$ 272 \\
\text { (US } \$ 488)\end{array}$ & $\begin{array}{l}\text { US } \$ 146 \\
\text { (US } \$ 58-\text { US } \$ 344)\end{array}$ \\
\hline Other outpatient, all-cause: & $\begin{array}{l}\text { US } \$ 2310 \\
\text { (US } \$ 2987)\end{array}$ & $\begin{array}{l}\text { US } \$ 1390 \\
\text { (US } \$ 680-\text { US } \$ 2704 \text { ) }\end{array}$ & $\begin{array}{l}\text { US } \$ 2771 \\
\text { (US } \$ 3220)\end{array}$ & $\begin{array}{l}\text { US } \$ 1843 \\
\text { (US } \$ 961-\text { US } \$ 3244)\end{array}$ & $\begin{array}{l}\text { US } \$ 1178 \\
\text { (US } \$ 2472)\end{array}$ & $\begin{array}{l}\text { US } \$ 417 \\
\text { (US } \$ 104-U S \$ 1161 \text { ) }\end{array}$ \\
\hline - DLBCL-related & $\begin{array}{l}\text { US } \$ 403 \\
\text { (US } \$ 1138)\end{array}$ & $\begin{array}{l}\text { US } \$ 79 \\
\text { (US } \$ 3-U S \$ 397 \text { ) }\end{array}$ & $\begin{array}{l}\text { US } \$ 511 \\
\text { (US } \$ 1391)\end{array}$ & $\begin{array}{l}\text { US } \$ 113 \\
\text { (US } \$ 0-\text { US } \$ 541)\end{array}$ & $\begin{array}{l}\text { US } \$ 106 \\
\text { (US\$308) }\end{array}$ & $\begin{array}{l}\text { US } \$ 0 \\
\text { (US } \$ 0-\text { US } \$ 32 \text { ) }\end{array}$ \\
\hline - Non-DLBCL-related & $\begin{array}{l}\text { US } \$ 1907 \\
\text { (US } \$ 2612)\end{array}$ & $\begin{array}{l}\text { US } \$ 1079 \\
\text { (US } \$ 528-\text { US } \$ 2260 \text { ) }\end{array}$ & $\begin{array}{l}\text { US } \$ 2260 \\
\text { (US } \$ 2766)\end{array}$ & $\begin{array}{l}\text { US } \$ 1466 \\
\text { (US } \$ 703-\text { US } \$ 2670 \text { ) }\end{array}$ & $\begin{array}{l}\text { US } \$ 1072 \\
\text { (US } \$ 2406)\end{array}$ & $\begin{array}{l}\text { US } \$ 356 \\
\text { (US } \$ 70-U S \$ 1002)\end{array}$ \\
\hline Chemoimmunotherapy & $\begin{array}{l}\text { US } \$ 3190 \\
\text { (US } \$ 3360)\end{array}$ & $\begin{array}{l}\text { US } \$ 2042 \\
\text { (US } \$ 925-\text { US } \$ 4564)\end{array}$ & $\begin{array}{l}\text { US } \$ 4121 \\
\text { (US } \$ 3104)\end{array}$ & $\begin{array}{l}\text { US } \$ 3406 \\
\text { (US } \$ 2447-U S \$ 5078 \text { ) }\end{array}$ & $\begin{array}{l}\text { US } \$ 650 \\
\text { (US } \$ 2734)\end{array}$ & $\begin{array}{l}\text { US } \$ 0 \\
\text { (US } \$ 0-\text { US } \$ 0 \text { ) }\end{array}$ \\
\hline Supportive care & $\begin{array}{l}\text { US } \$ 1254 \\
\text { (US } \$ 1351)\end{array}$ & $\begin{array}{l}\text { US } \$ 787 \\
\text { (US } \$ 274-\text { US } \$ 1819 \text { ) }\end{array}$ & $\begin{array}{l}\text { US } \$ 1680 \\
\text { (US } \$ 1287)\end{array}$ & $\begin{array}{l}\text { US } \$ 1746 \\
\text { (US } \$ 719-\text { US } \$ 2234 \text { ) }\end{array}$ & $\begin{array}{l}\text { US } \$ 120 \\
\text { (US } \$ 564)\end{array}$ & $\begin{array}{l}\text { US } \$ 0 \\
\text { (US } \$ 0-U S \$ 0)\end{array}$ \\
\hline Radiation & $\begin{array}{l}\text { US } \$ 913 \\
\text { (US } \$ 3100)\end{array}$ & $\begin{array}{l}\text { US } \$ 0 \\
\text { (US } \$ 0-\text { US } \$ 497 \text { ) }\end{array}$ & $\begin{array}{l}\text { US } \$ 1123 \\
\text { (US } \$ 3305)\end{array}$ & $\begin{array}{l}\text { US } \$ 0 \\
\text { (US } \$ 0-\text { US } \$ 1052 \text { ) }\end{array}$ & $\begin{array}{l}\text { US } \$ 257 \\
\text { (US } \$ 1515)\end{array}$ & $\begin{array}{l}\text { US } \$ 0 \\
\text { (US\$0-US } \$ 0 \text { ) }\end{array}$ \\
\hline SCT & $\begin{array}{l}\text { US } \$ 192 \\
\text { (US } \$ 1441)\end{array}$ & $\begin{array}{l}\text { US } \$ 0 \\
\text { (US } \$ 0-\text { US } \$ 0 \text { ) }\end{array}$ & $\begin{array}{l}\text { US } \$ 170 \\
\text { (US } \$ 1510)\end{array}$ & $\begin{array}{l}\text { US } \$ 0 \\
\text { (US } \$ 0-\text { US } \$ 0 \text { ) }\end{array}$ & $\begin{array}{l}\text { US } \$ 228 \\
\text { (US } \$ 1923)\end{array}$ & $\begin{array}{l}\text { US } \$ 0 \\
\text { (US } \$ 0-\text { US } \$ 0 \text { ) }\end{array}$ \\
\hline
\end{tabular}

and patients with aggressive NHL (US\$5871 vs US $\$ 355$ ) and indolent NHL (US\$3883 vs US\$289) incurred significantly higher costs compared with the control patients [11]. Our study did not evaluate costs separately for patients who progressed versus those who did not; these costs were counted toward the overall cost of these cancers. Other studies have shown that patients with indolent NHL who progressed incurred more costs compared with those who did not progress [12]. 
Table 6. Healthcare costs overall and during year 1 and 2 postindex date for treated follicular lymphoma patients.

\begin{tabular}{|c|c|c|c|c|c|c|}
\hline \multirow{2}{*}{$\begin{array}{l}\text { Cost, mean } 2015 \text { US } \$ \text { in PPPM } \\
\text { (SD) }\end{array}$} & \multicolumn{2}{|c|}{ Overall $(n=1221)$} & \multicolumn{2}{|c|}{ Year $1(n=1221)$} & \multicolumn{2}{|c|}{ Year $2(n=879)$} \\
\hline & Mean (SD) & Median (IQR) & Mean (SD) & Median (IQR) & Mean (SD) & Median (IQR) \\
\hline Total, all-cause: & $\begin{array}{l}\text { US } \$ 10,460 \\
\text { (US } \$ 13,871)\end{array}$ & $\begin{array}{l}\text { US } \$ 6926 \\
\text { (US } \$ 4039-\text { US } \$ 12,347 \text { ) }\end{array}$ & $\begin{array}{l}\text { US } \$ 12,183 \\
\text { (US } \$ 13,565)\end{array}$ & $\begin{array}{l}\text { US } \$ 9665 \\
\text { (US } \$ 6265-\text { US } \$ 14,009 \text { ) }\end{array}$ & $\begin{array}{l}\text { US } \$ 5062 \\
\text { (US } \$ 10,429)\end{array}$ & $\begin{array}{l}\text { US } \$ 3202 \\
\text { (US } \$ 941-U S \$ 5502)\end{array}$ \\
\hline - FL-related & $\begin{array}{l}\text { US } \$ 6482 \\
\text { (US } \$ 10,341)\end{array}$ & $\begin{array}{l}\text { US } \$ 4419 \\
\text { (US } \$ 2368-\text { US } \$ 7705 \text { ) }\end{array}$ & $\begin{array}{l}\text { US } \$ 7860 \\
\text { (US } \$ 10,249)\end{array}$ & $\begin{array}{l}\text { US } \$ 6399 \\
\text { (US } \$ 3837-\text { US } \$ 9615 \text { ) }\end{array}$ & $\begin{array}{l}\text { US } \$ 2742 \\
\text { (US } \$ 5560)\end{array}$ & $\begin{array}{l}\$ 1454 \\
\text { (US } \$ 28-U S \$ 3677 \text { ) }\end{array}$ \\
\hline - Non-FL-related & $\begin{array}{l}\text { US } \$ 3978 \\
\text { (US } \$ 6867)\end{array}$ & $\begin{array}{l}\text { US } \$ 1952 \\
\text { (US } \$ 1034-U S \$ 4098)\end{array}$ & $\begin{array}{l}\text { US } \$ 4323 \\
\text { (US } \$ 6926)\end{array}$ & $\begin{array}{l}\text { US } \$ 2356 \\
\text { (US } \$ 1181-U S \$ 4519)\end{array}$ & $\begin{array}{l}\text { US } \$ 2319 \\
\text { (US } \$ 8019)\end{array}$ & $\begin{array}{l}\text { US } \$ 895 \\
\text { (US } \$ 353-U S \$ 2022)\end{array}$ \\
\hline Medical, all-cause: & $\begin{array}{l}\text { US } \$ 10,147 \\
\text { (US } \$ 13,755)\end{array}$ & $\begin{array}{l}\text { US } \$ 6588 \\
\text { (US } \$ 3904-U S \$ 11,800)\end{array}$ & $\begin{array}{l}\text { US } \$ 11,866 \\
\text { (US } \$ 13,464)\end{array}$ & $\begin{array}{l}\text { US } \$ 9402 \\
\text { (US } \$ 5956-\text { US } \$ 13,695)\end{array}$ & $\begin{array}{l}\text { US } \$ 4795 \\
\text { (US } \$ 10,293)\end{array}$ & $\begin{array}{l}\text { US } \$ 2989 \\
\text { (US } \$ 812-\text { US } \$ 5160)\end{array}$ \\
\hline - FL-related & $\begin{array}{l}\text { US } \$ 6390 \\
\text { (US } \$ 10,308)\end{array}$ & $\begin{array}{l}\text { US } \$ 4338 \\
\text { (US } \$ 2304-\text { US } \$ 7649 \text { ) }\end{array}$ & $\begin{array}{l}\text { US } \$ 7766 \\
\text { (US } \$ 10,217)\end{array}$ & $\begin{array}{l}\text { US } \$ 6338 \\
\text { (US } \$ 3813-\text { US } \$ 9573 \text { ) }\end{array}$ & $\begin{array}{l}\text { US } \$ 2670 \\
\text { (US } \$ 5488)\end{array}$ & $\begin{array}{l}\text { US } \$ 1319 \\
\text { (US } \$ 23-\text { US } \$ 3630 \text { ) }\end{array}$ \\
\hline - Non-FL-related & $\begin{array}{l}\text { US } \$ 3757 \\
\text { (US } \$ 6793)\end{array}$ & $\begin{array}{l}\text { US } \$ 1789 \\
\text { (US } \$ 896-\text { US } \$ 3815 \text { ) }\end{array}$ & $\begin{array}{l}\text { US } \$ 4101 \\
\text { (US } \$ 6863)\end{array}$ & $\begin{array}{l}\text { US } \$ 2131 \\
\text { (US } \$ 1075-\text { US } \$ 4250 \text { ) }\end{array}$ & $\begin{array}{l}\text { US } \$ 2126 \\
\text { (US } \$ 7944)\end{array}$ & $\begin{array}{l}\text { US } \$ 724 \\
\text { (US } \$ 262-\text { US } \$ 1782 \text { ) }\end{array}$ \\
\hline Pharmacy, all-cause & $\begin{array}{l}\text { US } \$ 313 \\
\text { (US } \$ 667)\end{array}$ & $\begin{array}{l}\text { US } \$ 102 \\
\text { (US } \$ 22-U S \$ 311)\end{array}$ & $\begin{array}{l}\text { US } \$ 317 \\
\text { (US } \$ 730)\end{array}$ & $\begin{array}{l}\text { US } \$ 99 \\
\text { (US } \$ 20-U S \$ 315)\end{array}$ & $\begin{array}{l}\text { US } \$ 266 \\
\text { (US } \$ 772)\end{array}$ & $\begin{array}{l}\text { US } \$ 57 \\
\text { (US } \$ 6-\text { US } \$ 231)\end{array}$ \\
\hline \multicolumn{7}{|l|}{ Medical cost components } \\
\hline Inpatient, all-cause: & $\begin{array}{l}\text { US } \$ 1827 \\
\text { (US } \$ 6447)\end{array}$ & $\begin{array}{l}\text { US } \$ 29 \\
\text { (US } \$ 0-\text { US } \$ 1117 \text { ) }\end{array}$ & $\begin{array}{l}\text { US\$1905 } \\
(\$ 6532)\end{array}$ & $\begin{array}{l}\text { US } \$ 0 \\
\text { (US } \$ 0-U S \$ 1221 \text { ) }\end{array}$ & $\begin{array}{l}\text { US } \$ 651 \\
\text { (US } \$ 2586)\end{array}$ & $\begin{array}{l}\text { US } \$ 0 \\
\text { (US } \$ 0-U S \$ 0 \text { ) }\end{array}$ \\
\hline - FL-related & $\begin{array}{l}\text { US } \$ 276 \\
\text { (US } \$ 2345)\end{array}$ & $\begin{array}{l}\text { US } \$ 0 \\
\text { (US } \$ 0-\text { US } \$ 0 \text { ) }\end{array}$ & $\begin{array}{l}\text { US } \$ 323 \\
\text { (US } \$ 2386)\end{array}$ & $\begin{array}{l}\text { US } \$ 0 \\
\text { (US } \$ 0-\text { US } \$ 0 \text { ) }\end{array}$ & $\begin{array}{l}\text { US } \$ 30 \\
\text { (US } \$ 394)\end{array}$ & $\begin{array}{l}\text { US } \$ 0 \\
\text { (US } \$ 0-\text { US } \$ 0 \text { ) }\end{array}$ \\
\hline - Non-FL-related & $\begin{array}{l}\text { US } \$ 1551 \\
\text { (US\$5591) }\end{array}$ & $\begin{array}{l}\text { US } \$ 21 \\
\text { (US } \$ 0 \text {-US } \$ 924 \text { ) }\end{array}$ & $\begin{array}{l}\text { US } \$ 1582 \\
\text { (US\$5677) }\end{array}$ & $\begin{array}{l}\text { US } \$ 0 \\
\text { (US } \$ 0-U S \$ 887 \text { ) }\end{array}$ & $\begin{array}{l}\text { US } \$ 621 \\
\text { (US } \$ 2481)\end{array}$ & $\begin{array}{l}\text { US } \$ 0 \\
\text { (US } \$ 0-\text { US } \$ 0 \text { ) }\end{array}$ \\
\hline ED, all-cause: & $\begin{array}{l}\text { US } \$ 152 \\
\text { (US } \$ 431)\end{array}$ & $\begin{array}{l}\text { US } \$ 17 \\
\text { (US } \$ 0-\$ 144)\end{array}$ & $\begin{array}{l}\text { US } \$ 151 \\
\text { (US } \$ 446)\end{array}$ & $\begin{array}{l}\text { US } \$ 0 \\
\text { (US } \$ 0 \text {-US } \$ 129 \text { ) }\end{array}$ & $\begin{array}{l}\text { US } \$ 90 \\
\text { (US } \$ 271)\end{array}$ & $\begin{array}{l}\text { US } \$ 0 \\
\text { (US } \$ 0 \text {-US } \$ 39 \text { ) }\end{array}$ \\
\hline - FL-related & $\begin{array}{l}\text { US } \$ 11 \\
\text { (US } \$ 213)\end{array}$ & $\begin{array}{l}\text { US } \$ 0 \\
\text { (US } \$ 0-U S \$ 0 \text { ) }\end{array}$ & $\begin{array}{l}\text { US } \$ 12 \\
\text { (US } \$ 214)\end{array}$ & $\begin{array}{l}\text { US } \$ 0 \\
\text { (US } \$ 0-U S \$ 0 \text { ) }\end{array}$ & $\begin{array}{l}\text { US } \$ 2 \\
\text { (US } \$ 31)\end{array}$ & $\begin{array}{l}\text { US } \$ 0 \\
\text { (US } \$ 0-U S \$ 0 \text { ) }\end{array}$ \\
\hline - Non-FL-related & $\begin{array}{l}\text { US } \$ 141 \\
\text { (US } \$ 375)\end{array}$ & $\begin{array}{l}\text { US } \$ 15 \\
\text { (US } \$ 0-\text { US } \$ 135 \text { ) }\end{array}$ & $\begin{array}{l}\text { US } \$ 139 \\
\text { (US } \$ 391)\end{array}$ & $\begin{array}{l}\text { US } \$ 0 \\
\text { (US } \$ 0-U S \$ 121)\end{array}$ & $\begin{array}{l}\text { US } \$ 88 \\
\text { (US } \$ 268)\end{array}$ & $\begin{array}{l}\text { US } \$ 0 \\
\text { (US } \$ 0-\text { US } \$ 36)\end{array}$ \\
\hline Physician office, all-cause: & $\begin{array}{l}\text { US } \$ 682 \\
\text { (US } \$ 810)\end{array}$ & $\begin{array}{l}\text { US } \$ 453 \\
\text { (US } \$ 234-\text { US } \$ 836 \text { ) }\end{array}$ & $\begin{array}{l}\text { US } \$ 817 \\
\text { (US } \$ 863 \text { ) }\end{array}$ & $\begin{array}{l}\text { US } \$ 597 \\
\text { (US } \$ 287-U S \$ 1100 \text { ) }\end{array}$ & $\begin{array}{l}\text { US } \$ 378 \\
\text { (US } \$ 575)\end{array}$ & $\begin{array}{l}\text { US } \$ 218 \\
\text { (US } \$ 107-U S \$ 471)\end{array}$ \\
\hline - FL-related & $\begin{array}{l}\text { US } \$ 226 \\
\text { (US } \$ 484)\end{array}$ & $\begin{array}{l}\text { US } \$ 82 \\
\text { (US } \$ 9-\text { US } \$ 234 \text { ) }\end{array}$ & $\begin{array}{l}\text { US } \$ 292 \\
\text { (US } \$ 528)\end{array}$ & $\begin{array}{l}\text { US } \$ 118 \\
\text { (US } \$ 10-\text { US } \$ 368 \text { ) }\end{array}$ & $\begin{array}{l}\text { US } \$ 83 \\
\text { (US } \$ 215)\end{array}$ & $\begin{array}{l}\text { US } \$ 16 \\
\text { (US\$0-US\$74) }\end{array}$ \\
\hline - Non-FL-related & $\begin{array}{l}\text { US } \$ 455 \\
\text { (US } \$ 608)\end{array}$ & $\begin{array}{l}\text { US } \$ 278 \\
\text { (US } \$ 126-\text { US } \$ 553)\end{array}$ & $\begin{array}{l}\text { US } \$ 525 \\
\text { (US } \$ 652)\end{array}$ & $\begin{array}{l}\text { US } \$ 351 \\
\text { (US } \$ 133-\text { US } \$ 696 \text { ) }\end{array}$ & $\begin{array}{l}\text { US } \$ 294 \\
\text { (US\$528) }\end{array}$ & $\begin{array}{l}\text { US } \$ 154 \\
\text { (US } \$ 70-U S \$ 358 \text { ) }\end{array}$ \\
\hline Other outpatient, all-cause: & $\begin{array}{l}\text { US } \$ 2169 \\
\text { (US } \$ 4049)\end{array}$ & $\begin{array}{l}\text { US } \$ 1191 \\
\text { (US } \$ 592-U S \$ 2391 \text { ) }\end{array}$ & $\begin{array}{l}\text { US } \$ 2535 \\
\text { (US } \$ 4148)\end{array}$ & $\begin{array}{l}\text { US } \$ 1643 \\
\text { (US } \$ 827-U S \$ 2936 \text { ) }\end{array}$ & $\begin{array}{l}\text { US } \$ 1300 \\
\text { (US } \$ 7358)\end{array}$ & $\begin{array}{l}\text { US } \$ 458 \\
\text { (US } \$ 101-U S \$ 1053)\end{array}$ \\
\hline - FL-related & $\begin{array}{l}\text { US } \$ 559 \\
\text { (US } \$ 2479)\end{array}$ & $\begin{array}{l}\text { US } \$ 161 \\
\text { (US } \$ 11-U S \$ 519)\end{array}$ & $\begin{array}{l}\text { US } \$ 680 \\
\text { (US } \$ 2496)\end{array}$ & $\begin{array}{l}\text { US } \$ 257 \\
\text { (US } \$ 10-U S \$ 751)\end{array}$ & $\begin{array}{l}\text { US } \$ 177 \\
\text { (US } \$ 691)\end{array}$ & $\begin{array}{l}\text { US } \$ 0 \\
\text { (US } \$ 0-\text { US } \$ 81)\end{array}$ \\
\hline - Non-FL-related & $\begin{array}{l}\text { US } \$ 1610 \\
\text { (US } \$ 2580)\end{array}$ & $\begin{array}{l}\text { US } \$ 848 \\
\text { (US } \$ 422-\text { US } \$ 1753 \text { ) }\end{array}$ & $\begin{array}{l}\text { US } \$ 1855 \\
\text { (US } \$ 2741)\end{array}$ & $\begin{array}{l}\text { US } \$ 1116 \\
\text { (US } \$ 500-\text { US } \$ 2058 \text { ) }\end{array}$ & $\begin{array}{l}\text { US } \$ 1123 \\
\text { (US } \$ 7311)\end{array}$ & $\begin{array}{l}\text { US } \$ 309 \\
\text { (US } \$ 53-U S \$ 899)\end{array}$ \\
\hline Chemoimmunotherapy & $\begin{array}{l}\text { US } \$ 3941 \\
\text { (US } \$ 6579)\end{array}$ & $\begin{array}{l}\text { US } \$ 2968 \\
\text { (US } \$ 1410 \text {-US } \$ 5119 \text { ) }\end{array}$ & $\begin{array}{l}\text { US } \$ 4874 \\
\text { (US } \$ 6665)\end{array}$ & $\begin{array}{l}\text { US } \$ 4149 \\
\text { (US } \$ 2196-\text { US } \$ 6480 \text { ) }\end{array}$ & $\begin{array}{l}\text { US } \$ 1711 \\
\text { (US\$2270) }\end{array}$ & $\begin{array}{l}\text { US } \$ 34 \\
\text { (US } \$ 0-\text { US } \$ 3075 \text { ) }\end{array}$ \\
\hline Supportive care & $\begin{array}{l}\text { US } \$ 677 \\
\text { (US } \$ 1127)\end{array}$ & $\begin{array}{l}\text { US } \$ 137 \\
\text { (US } \$ 0-\text { US } \$ 860)\end{array}$ & $\begin{array}{l}\text { US } \$ 889 \\
\text { (US } \$ 1226)\end{array}$ & $\begin{array}{l}\text { US } \$ 23 \\
\text { (US } \$ 0 \text {-US } \$ 1825 \text { ) }\end{array}$ & $\begin{array}{l}\text { US } \$ 135 \\
\text { (US\$562) }\end{array}$ & $\begin{array}{l}\text { US } \$ 0 \\
\text { (US } \$ 0-\text { US } \$ 0 \text { ) }\end{array}$ \\
\hline Radiation & $\begin{array}{l}\text { US } \$ 578 \\
\text { (US } \$ 3470)\end{array}$ & $\begin{array}{l}\text { US } \$ 0 \\
\text { (US } \$ 0-\text { US } \$ 0 \text { ) }\end{array}$ & $\begin{array}{l}\text { US } \$ 601 \\
\text { (US } \$ 3437)\end{array}$ & $\begin{array}{l}\text { US } \$ 0 \\
\text { (US } \$ 0-\text { US } \$ 0 \text { ) }\end{array}$ & $\begin{array}{l}\text { US } \$ 377 \\
\text { (US } \$ 4210)\end{array}$ & $\begin{array}{l}\text { US } \$ 0 \\
\text { (US } \$ 0-\text { US } \$ 0 \text { ) }\end{array}$ \\
\hline SCT & $\begin{array}{l}\text { US } \$ 121 \\
\text { (US } \$ 1128)\end{array}$ & $\begin{array}{l}\text { US } \$ 0 \\
\text { (US } \$ 0-\text { US } \$ 0 \text { ) }\end{array}$ & $\begin{array}{l}\text { US } \$ 95 \\
\text { (US } \$ 1160)\end{array}$ & $\begin{array}{l}\$ 0 \\
\text { (US } \$ 0-\text { US } \$ 0 \text { ) }\end{array}$ & $\begin{array}{l}\text { US } \$ 154 \\
\text { (US } \$ 1552)\end{array}$ & $\begin{array}{l}\text { US } \$ 0 \\
\text { (US } \$ 0-\text { US } \$ 0 \text { ) }\end{array}$ \\
\hline
\end{tabular}

ED: Emergency department; FL: Follicular lymphoma; IQR: Interquartile range; PPPM: Per-patient per-month; SCT: Stem cell transplant; SD: Standard deviation.

Costs associated with non-DLBCL-related and non-FL-related inpatient admission and nonphysician office decreased following the first year. While reasons for the non-DLBCL-related and non-FL-related costs were not evaluated in detail, it is possible that some of these costs were due to the disease or treatment-related complications. Evaluation of the primary diagnoses associated with these claims showed that the top diagnoses were general cancer or general chemotherapy codes. Similar to our study, the previously mentioned study by Kutikova and colleagues also identified inpatient admissions as a major cost contributor, as were outpatient office visits [11]. 
The current study did not evaluate the setting of chemotherapy administration; however, rituximab was a component of the majority of the chemotherapy regimens, and cost differences in the setting of care for the administration of rituximab have been reported. A retrospective claims study reported an increase in the proportion of patients receiving rituximab treatment for NHL and chronic lymphocytic leukemia in the hospital outpatient setting [13]. Additionally, receipt of rituximab in the hospital outpatient setting was associated with higher total healthcare costs, higher infusion day drug and administration costs and higher rates of ED visits and inpatient stays than treatment given in a physician office or clinic [13].

Since our study was conducted, there have been changes in the treatment landscape of DLBCL with the approval of a chimeric antigen receptor T-cell therapy, axicabtagene ciloleucel. Axicabtagene ciloleucel was approved by the US FDA in 2017, for the treatment of adult patients with relapsed or refractory large B-cell lymphoma after two or more lines of systemic therapy, and have demonstrated improvement in treatment response. This represents a novel treatment option for relapse or refractory DLBCL patients, and is expected to impact the treatment cost of DLBCL. Among eligible patients, the average potential annual budget impact when using the cost of axicabtagene ciloleucel infusion was estimated to be US $\$ 184,000$ per-patient [14]. However, the cost-effectiveness analyses showed that the use of this therapy provides clinical benefit in terms of gains in quality-adjusted and overall survival over chemotherapy [14]. Given the recent approval of this therapy, the treated DLBCL population in our study did not include patients with this therapy. But, the costs reported in this study still remains relevant as it highlights the costs of this disease among those treated with chemoimmunotherapy or SCT. Also, it is likely that not all relapse or refractory DLBCL patients will be eligible to receive this treatment.

\section{Limitations}

The limitations of this study include those inherent to any retrospective study. Not all relevant characteristics can be captured through the use of diagnosis codes, including but not limited to, the International Prognostic Index risk factors and tissue information for genetic mutations. The actual healthcare costs associated with DLBCL or FL and their treatment might be underestimated, as related costs without a corresponding DLBCL or FL diagnosis code or treatment were categorized as non-DLBCL-related and non-FL-related costs. Furthermore, indirect costs, such as productivity loss or other out-of-pocket expenses, could not be captured from the Optum claims database.

\section{Conclusion}

The economic burden of treated DLBCL and FL is considerable, particularly in the first year of diagnosis, which is the period when the majority of patients received treatment. Costs of DLBCL and FL chemoimmunotherapy administration are major contributors to the overall costs in each cohort. Additionally, costs unrelated to DLBCL and $\mathrm{FL}$ - particularly in the inpatient and nonphysician office outpatient settings - were also major contributors. As treatment of DLBCL and FL continues to evolve, economic impact and healthcare utilization need to be further investigated in this patient population.

\section{Summary points}

- Among these newly diagnosed diffuse large B-cell lymphoma (DLBCL) and follicular lymphoma (FL) patients who received treatment for their disease, utilization of healthcare services decreased from the first year to the second year following diagnosis.

- Mean total costs from the time of diagnosis to the end of follow-up was US $\$ 11,890$ per-patient, per-month for DLBCL patients; of which, $56 \%$ were DLBCL-related costs.

- For FL patients, the mean total cost from the time of diagnosis to the end of follow-up was US $\$ 10,460$ per-patient, per-month, and $62 \%$ of these costs were FL-related costs.

- Costs in both cohorts also decreased from the first year to the second year following diagnosis, due to a decrease in the chemoimmunotherapy administration costs, a major contributor to the total costs, as well as inpatient admissions and nonphysician office outpatient service costs.

- The economic burden of treated DLBCL and FL is considerable, particularly in the first year of diagnosis, which is the period when the majority of patients received treatment.

- As treatment of DLBCL and FL continues to evolve, economic impact need to be further investigated in these populations. 
Authors' contributions

All authors contributed to the concept and design of the study, interpretation of the results, writing and revisions of the manuscript and approval of the final version submitted for publication. L Hamilton, A Ogbonnaya, K Hennenfent and M Eaddy conducted the analysis.

Financial \& competing interest disclosure

This study was funded by Millennium Pharmaceuticals Inc., Cambridge, MA, USA, a wholly owned subsidiary of Takeda Pharmaceutical Company Ltd Xcenda, LLC received funding from Takeda to conduct this study and develop the manuscript. VA Morrison has served as a consultant to Takeda. A Galaznik, JA Bell and Y Shou are employees of Takeda and have equity ownership. L Hamilton, A Ogbonnaya, K Hennenfent and M Eaddy are employees of Xcenda, LLC. The authors have no other relevant affiliations or financial involvement with any organization or entity with a financial interest in or financial conflict with the subject matter or materials discussed in the manuscript apart from those disclosed.

No writing assistance was utilized in the production of this manuscript.

Open access

This work is licensed under the Attribution-NonCommercial-NoDerivatives 4.0 Unported License. To view a copy of this license, visit http://creativecommons.org/licenses/by-nc-nd/4.0/

\section{References}

Papers of special note have been highlighted as: $\bullet$ of interest

1. American Cancer Society. Cancer facts and figures (2017). www.cancer.org/content/dam/cancer-org/research/cancer-facts-and-statistics /annual-cancer-facts-and-figures/2017/cancer-facts-and-figures-2017.pdf

2. Morton LM, Wang SS, Devesa SS, Hartge P, Weisenburger DD, Linet MS. Lymphoma incidence patterns by WHO subtype in the United States, 1992-2001. Blood 107(1), 265-276 (2006).

3. National Institute Health: SEER database. Fast facts. https://seer.cancer.gov/faststats/selections.php?\#Output

4. Chihara D, Nastoupil L, Williams J, Lee Paul et al. New insights into the epidemiology of non-Hodgkin lymphoma and implications for therapy. Expert Rev. Anticancer Ther. 15(5), 531-544 (2015).

5. Freedman A. Follicular lymphoma: 2015 update on diagnosis and management. Am. J. Hematol. 90(12), 1171-1178 (2015).

6. Link BK, Maurer MJ, Nowakowski GS et al. Rates and outcomes of follicular lymphoma transformation in the immunochemotherapy era: a report from the University of Iowa/Mayo Clinic Specialized Program of Research Excellence Molecular Epidemiology Resource. J. Clin. Oncol. 31(26), 3272-3278 (2013).

7. National Comprehensive Cancer Network. B cell lymphomas. V.3.2018. (2018) Fort Washington, PA, USA. www.nccn.org/professionals/physician_gls/pdf/b-cell.pdf

8. Nowakowski GS, Blum KA, Kahl BS et al. Beyond R-CHOP: a blueprint for diffuse large B cell lymphoma research. J. Natl Cancer Inst. 108(12), pii:djw25 (2016).

9. Bello C, Zhang L, Naghashpour M. Follicular lymphoma: current management and future directions. Cancer Control 19(3), 171-172 (2012).

10. Mariotto AB, Yabroff KR, Shao Y et al. Projections of the cost of cancer care in the United States: 2010-2020. J. Natl Cancer Inst. 103(2), 117-128 (2011).

- Changes in the US population alone are projected to result in a cost increase of $27 \%$ by 2020 . The increase in costs is attributed to factors including the aging population, along with advances in diagnostic technology and novel targeted treatments. This article is important because it reports on the rising cost of cancer care, and factors contributing to this increase include the aging population and use of targeted treatments. Both factors are very relevant to diffuse large B-cell lymphoma and follicular lymphoma (FL). However, few studies have evaluated the overall cost of treatment of these diseases.

11. Kutikova L, Bowman L, Chang S et al. Medical costs associated with non-Hodgkin's lymphoma in the United States during the first two years of treatment. Leuk. Lymphoma 47(8), 1535-1544 (2006).

- A retrospective cohort analysis was conducted using 1999-2000 claims data to evaluate the medical costs associated with aggressive and indolent non-Hodgkin's lymphoma (NHL) in the USA; to show the changes across the different treatment phases for aggressive NHL; and cost of treatment failure in aggressive NHL. Mean monthly costs for patients with aggressive and indolent NHL were significantly greater than that for the controls. For aggressive NHL, mean monthly initial treatment phase costs and palliative care costs were higher than costs incurred during secondary phase. The mean cost of treatment failure in aggressive NHL was US $\$ 14,174$ per month, and US $\$ 85,934$ over the study period. This study quantified the high economic burden of aggressive and indolent NHL, as well as costs of treatment failure for aggressive NHL. It also showed that costs incurred during the initial treatment and palliative care phases were highest. 
12. Beveridge R, Satram-Hoang S, Sail K et al. Economic impact of disease progression in follicular non-Hodgkin lymphoma. Leuk. Lymphoma 52(11), 2117-2123 (2011).

- The economic cost of progression was evaluated among patients diagnosed with FL, and they were treated in an outpatient community-based setting between July 2006 and December 2009. The study found that the mean overall cost per-patient, per-month over a 6-month follow-up period was significantly higher for patients with progressive disease versus nonprogressive disease. This study highlighted and quantified costs associated with FL progression among patients treated within an outpatient community-based setting, but over a short time period. The study also showed treatment strategies that delay or prevent progression improve clinical outcomes and lower the economic burden of the disease.

13. DaCosta Byfield S, Small A, Becker LK, Reyes CM. Differences in treatment patterns and health care costs among non-Hodgkin's lymphoma and chronic lymphocytic leukemia patients receiving rituximab in the hospital outpatient setting versus the office/clinic setting. J. Cancer Ther. 5(2), 208-216 (2014).

- This retrospective cohort study used claims data from January 2007 to July 2012 to examine whether differences in treatment patterns and healthcare costs exist among chronic lymphocytic leukemia and NHL patients receiving rituximab in a hospital outpatient setting versus those receiving rituximab in a physician office/community clinic setting. Results of the study showed that the percentage of patients receiving rituximab in the hospital outpatient setting increased from $22 \%$ in 2007 to $39 \%$ in 2012. Patients treated in the hospital outpatient setting versus the office/clinic setting had fewer average counts of rituximab infusions, higher total healthcare costs, higher infusion day drug and administration costs and higher rates of emergency department visits and inpatient stays. This study showed that there may be differences by site of service in treatment patterns and healthcare costs among NHL and chronic lymphocytic leukemia patients receiving rituximab.

14. Institute for Clinical and Economic Review. Chimeric antigen receptor T-cell therapy for B-cell cancers: effectiveness and value, 23 March (2018). https://icer-review.org/wp-content/uploads/2017/07/ICER_CAR_T_Final_Evidence_Report_032318.pdf 